Hydrology, Water Quality, and Potential Alternatives for Water-Resources Development in the Río Majada and Río Lapa Basins Near the Albergue Olímpico, Southern Puerto Rico

By Orlando Ramos-Ginés

U.S. GEOLOGICAL SURVEY

Water-Resources Investigations Report 91-4174

Prepared in cooperation with the PUERTO RICO ENVIRONMENTAL QUALITY BOARD and the CENTER FOR SPORT HEALTH AND EXERCISE SCIENCE OF THE ALBERGUE OLÍMPICO 


\section{U.S. DEPARTMENT OF THE INTERIOR}

BRUCE BABBITT, Secretary

U.S. GEOLOGICAL SURVEY

Robert M. Hirsch, Acting Director

For additional information write to:

District Chief

U.S. Geological Survey

P.O. Box 364424

San Juan, Puerto Rico 00936-4424
Copies of this report can be purchased from:

U.S. Geological Survey Earth Science Information Center Open-File Reports Section Box 25286, MS 517, Denver Federal Center Denver, CO 80225 


\section{CONTENTS}

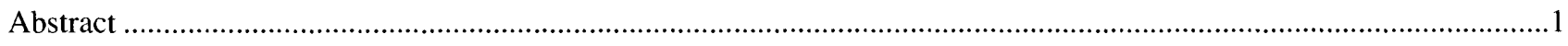

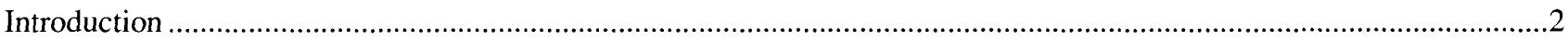

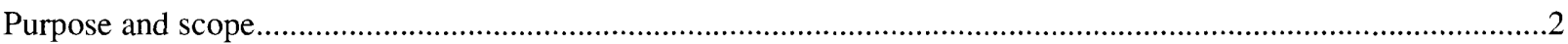

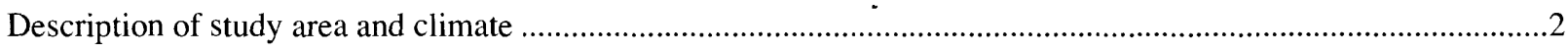

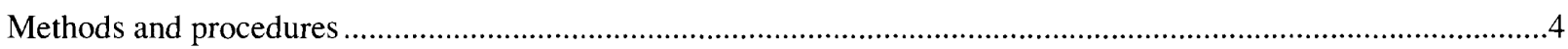

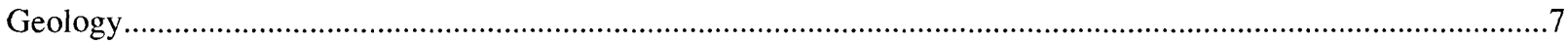

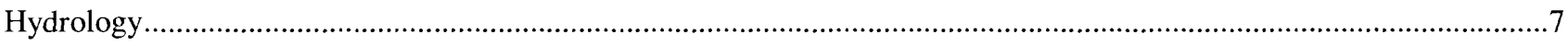

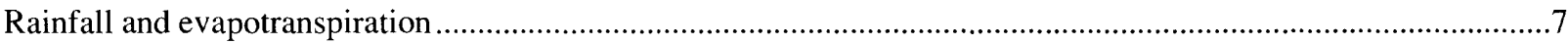

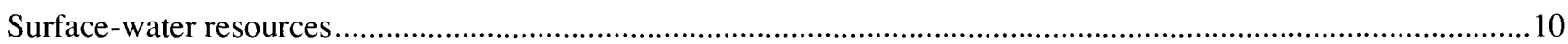

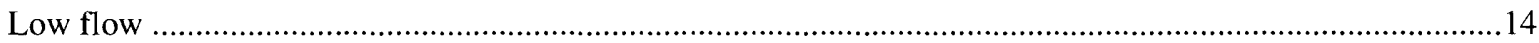

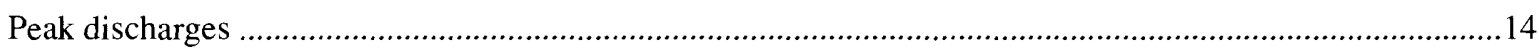

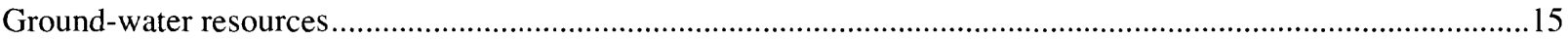

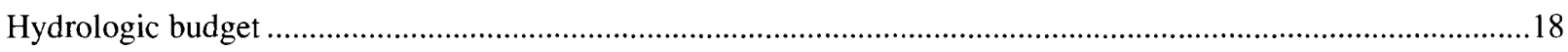

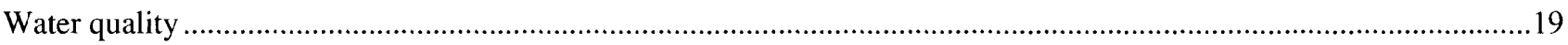

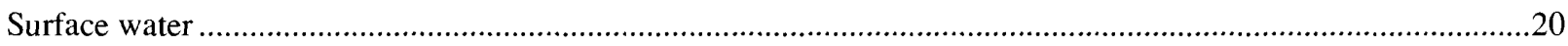

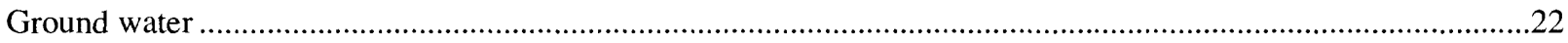

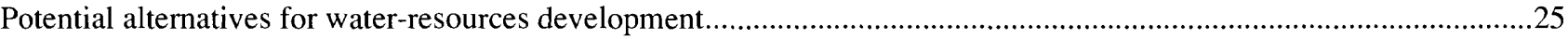

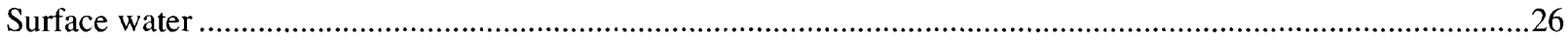

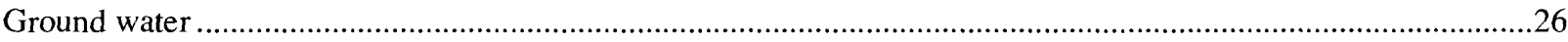

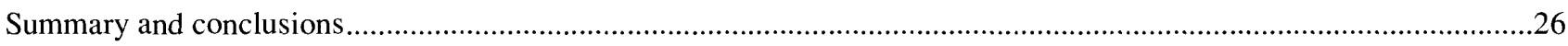

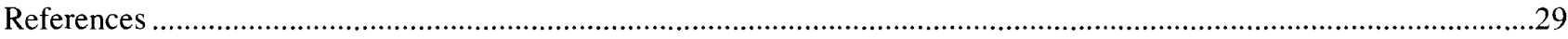

Appendix--Physical properties and chemical and bacteriological

characteristics of water from streams and selected wells ............................................................................ 


\section{FIGURES}

1. Map showing location of the Río Majada and Río Lapa basins, study area, and surface-water, pan evaporation-rainfall, and rainfall data-collection sites

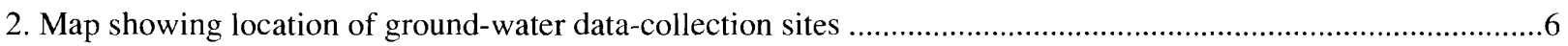

3. Map showing generalized geology of the Río Majada and Río Lapa basins …..................................................

4. Map showing location of geologic sections A-A' and B-B' and control points in

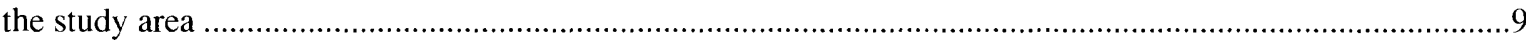

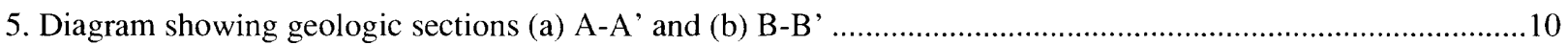

6-9. Graphs showing:

6. Rainfall in the (a) study area, (b) Río Majada headwaters, and (c) pan

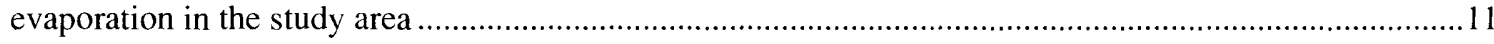

7. Daily-mean discharges of the Río Majada and the Río Lapa during 1989 .......................................................12

8. Low-flow frequency curves for the (a) Río Majada at La Plena (site 1) and (b) Río Lapa near Rabo del Buey (site 2) as estimated from the Río Patillas

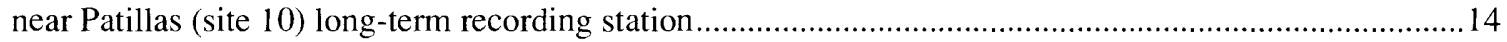

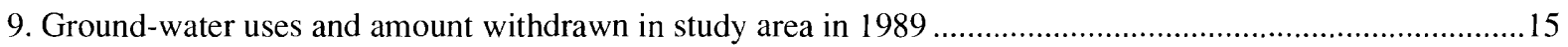

10. Map showing ground-water levels during July 26 and October 18,1989 in the study area ..............................16

11-19. Graphs showing:

11. Ground-water level fluctuations at recording wells in the study area......

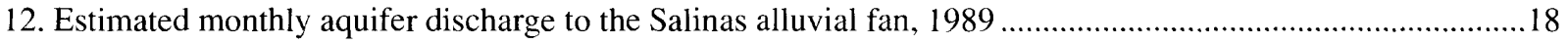

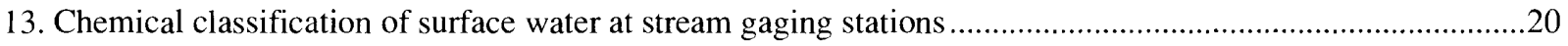

14. Dissolved concentrations of selected ions in study-area streams during 1989 ...............................................21

15. Fecal bacteria counts (fecal coliform plus fecal streptococcus) at the Río Majada

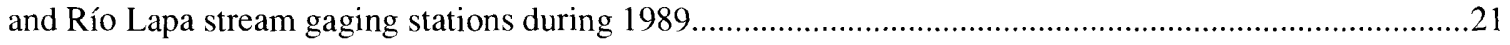

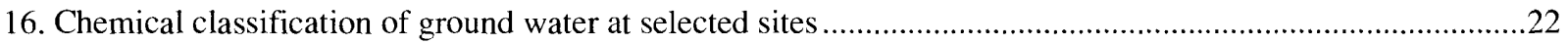

17. Dissolved concentrations of selected ions in the ground water at selected sites during 1989.

18. Projection of water demand to the year 1995 in the Río Majada and Río Lapa

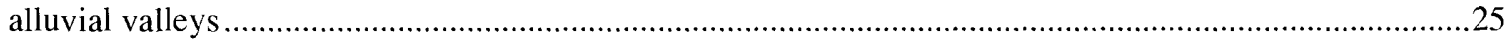

19. Ten-year moving average rainfall pattern at selected rainfall stations in Puerto Rico ...................................26

\section{TABLES}

1. Identification of data-collection sites .5

2. Infiltration rates based on streamflow discharge measurements conducted from December 1988 to December 1989

3. Low flows for the Río Majada and Río Lapa gaging stations during 1989.

4. Aquifer hydraulic-conductivity values as estimated from slug-injection and specific-capacity tests.

5. Hydrologic budget of the Río Majada to Río Lapa Valleys for 1989 ...............................................................19

6. Fecal coliform and fecal streptococcus bacteria concentrations during 1989 


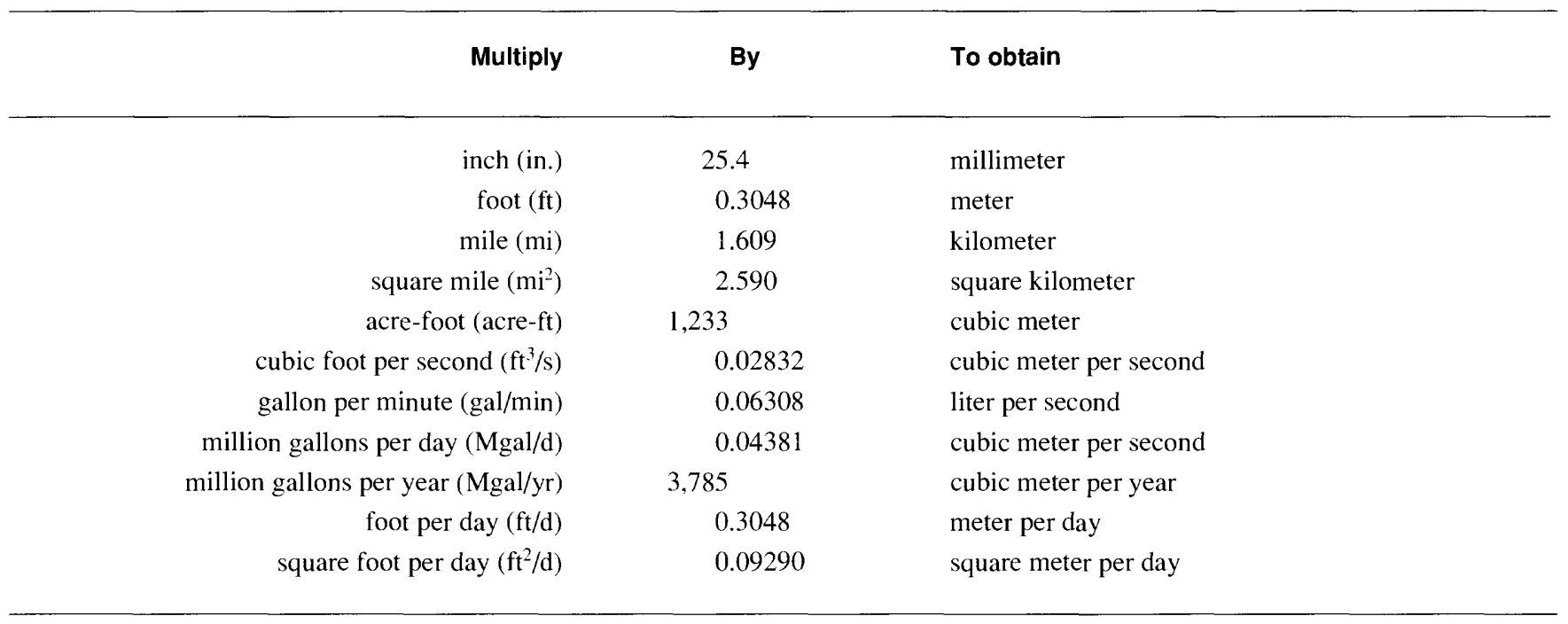

Temperature in degrees Fahrenheit $\left({ }^{\circ} \mathrm{F}\right)$ may be converted to degrees Celsius $\left({ }^{\circ} \mathrm{C}\right)$ as follows: ${ }^{\circ} \mathrm{C}=5 / 9\left({ }^{\circ} \mathrm{F}-32\right)$

\section{Abbreviated water-quality units used in this report:}

micrograms per liter $(\mu \mathrm{g} / \mathrm{L})$

milligrams per liter $(\mathrm{mg} / \mathrm{L})$

microsiemens per centimeter at $25^{\circ} \mathrm{C}(\mu \mathrm{S} / \mathrm{cm})$

colony per 100 milliliter $(\mathrm{col} / 100 \mathrm{ml})$

\section{Acronyms used in this report:}

National Oceanic and Atmospheric Administration (NOAA)

Volatile Organic Compound (VOC) 


\title{
Hydrology, Water Quality, and Potential Alternatives for Water- Resources Development in the Río Majada and Río Lapa Basins Near the Albergue Olímpico, Southern Puerto Rico
}

\author{
By Orlando Ramos-Ginés
}

\begin{abstract}
A water-resources investigation was conducted during 1988 to 1989 in the Río Majada and Río Lapa basins in southern Puerto Rico, to define the occurrence, availability, and quality of the water resources, and to describe alternatives for additional water supply. These basins provide surface and ground-water flows to the Salinas alluvial fan, one of the major parts of the south coast alluvial aquifer system. The climate of these basins is characterized by extensive dry periods and high evaporation rates. Rainfall differences between dry and wet seasons substantially alter streamflow and ground-water levels.
\end{abstract}

Streamflow varied seasonally in response to rainfall in the basins during the study period. The average daily flow recession for both streams at gaging stations was 0.01 cubic feet per second per day from January to August 1989 (dry season). Streamflow increased from September to October, when most of the rainfall occurred in the basins. Diversion of surface water to areas outside the study area prevents about 40 percent of the streamflow from recharging the aquifer.

Inflows and outflows of both surface water and ground water in the alluvial area of the basins were estimated to be 7,530 acre-feet in 1989. Streamflow was the greatest inflow component of the overall hydrologic budget and accounted for 77 percent (5,790 acre-feet) of the total inflow to the Río Majada and Río Lapa alluvial valleys. Streamflow out of the study area (3,900 acre-feet per year, or 52 percent of total outflow) and evapotranspiration (2,370 acre-feet per year, or 31 percent) were the largest outflow components of the overall hydrologic budget.

The water budget of the ground-water system in the study area was estimated to be 2,760 acre-feet in 1989. Aquifer recharge from streamflow seepage $(2,240$ acre-feet per year) was the greatest inflow component of the ground-water budget, and accounted for 81 percent of the total inflow to the study area. Evapotranspiration from ground water was the greatest outflow component, accounting for 54 percent $(1,500$ acre-feet per year) of the ground- water budget. Ground-water withdrawals totaled about 330 acre-feet $(12$ percent) during 1989.

Chemical analyses of surface-water samples collected at monthly intervals during 1989 at gaging stations indicate that the water is predominantly a calcium-bicarbonate type. Dissolved-solids concentrations in surface-water samples ranged from 305 to 457 milligrams per liter, and fecal bacteria concentrations ranged from 23 to 7,200 colonies per 100 milliliters. Analyses of ground-water samples collected at monthly intervals during 1989 indicate that the water is predominantly a calcium-bicarbonate type. Dissolved-solids concentrations in ground-water samples ranged from 352 to 516 milligrams per liter, and fecal bacteria concentrations ranged from less than 1 to 704 colonies per 100 milliliters. The concentration of fecal bacteria increased during the dry season from 23 to about 4,700 colonies per 100 milliliters in the surface water and from less than 1 to 704 colonies per 100 milliliters in the ground water. The concentration of fecal bacterias in the surface water on October 16, 1989 (wet season) was at 2,670 and 7,200 colonies per 100 milliliters, for the Río Majada and Río Lapa, respectively, which exceeded the recommended fecal bacteria concentration for natural waters.

Existing water resources could be developed to meet the projected demands of 110 acre-feet in 1995, unless there is a major drought or unless there is a need to continue releasing surface-water flow, or a need to continue allowing ground-water flow to the Salinas alluvial fan. Storage of surface-water runoff during the wet season may be used, after treatment, to supply the expected water demand in the study area. Alternatively, the stored water could be gradually released to the study area to provide additional aquifer recharge to offset reduced ground-water levels during the dry season or may be used to supplement the ground-water flow to the Salinas alluvial fan. 


\section{INTRODUCTION}

An increasing demand for water and a limited supply of both ground water and surface water are common problems on the south coast of Puerto Rico. Low rainfall during the extended dry period, which is common in southern Puerto Rico, results in reduced water availability. Flow in the few perennial streams. which discharge to the coalesced alluvial fans that form the South Coastal Plain, is an important source of recharge to the alluvial aquifer during the dry season. Water-resources investigations have shown that the annual dry periods from January to August caused serious shortages in both surface and ground water (Díaz, 1974a, b; Giusti, 1968, 1971 a, b). Streamflow may decrease annually by at least 80 percent and ground-water levels may decline by about $10 \mathrm{ft}$, because of the decrease in aquifer recharge by rainfall and streamflow seepage during the January to August dry season.

The Río Majada and Río Lapa basins are at the headwaters of the Salinas alluvial fan (fig. 1), which is a major part of the south coast alluvial aquifer system. Streamflow from these basins is an important source of water for the Salinas alluvial fan, both as surface water and as recharge to the aquifer during the annual wet season, and as ground-water flow throughout the year.

In the southern part of the Río Majada and Río Lapa basins, ground-water withdrawals have increased since 1986 to meet the water-supply needs of the Albergue Olímpico (fig. 1), a facility used for training athletes and for public recreation. Prior to 1986 , the average ground-water withdrawal rate was 0.13 $\mathrm{Mgal} / \mathrm{d}$, but by 1989 , withdrawals had increased to $0.29 \mathrm{Mgal} / \mathrm{d}$. Water-supply demands at the new facilities are expected to increase an additional $0.10 \mathrm{Mgal} / \mathrm{d}$ by 1995 (J. Cruz-Vález. Albergue Olímpico, oral commun., 1990). The development of the water resources to supply the expected water demand may affect both surface- and ground-water flow to the Salinas alluvial fan.

In addition to the generally limited water supply. contaminants from rapidly expanding poultry farms and suburban development pose potential water-quality problems in both the Río Majada-Río Lapa basins and the Salinas alluvial fan. Concentrations of inorganic and organic constituents and fecal bacteria content may increase as surface- and ground-water resources are depleted. Little is known about the effects of dry periods on the water quality in mountain basins that discharge to the South Coastal Plain of Puerto Rico.

Public agencies are concerned about water availability to meet the growing demand, the potential effects of dry periods on the water quality, and the potential effects of the waterresources development in the Río Majada and Río Lapa basins on the inflow of water to the Salinas alluvial fan. In response to these concerns, the U.S. Geological Survey entered into a cooperative study in 1988 with the Puerto Rico Environmental Quality Board and the Center for Sport Health and Exercise Science of the Albergue Olímpico. the later of which is administered by the University of Puerto Rico, Medical Science Campus.

\section{Purpose and Scope}

The purpose of this report is to present the results of an investigation to define the occurrence, availability, and quality of the water resources in the southern part of the Río Majada and Río Lapa basins: and to describe potential alternatives for additional water supply. The investigation was designed to provide an understanding of the hydrology of the Río Majada and Río Lapa basins. with emphasis on the alluvial valleys area near the Albergue Olímpico, as a basis for water-resources management. As part of this investigation, hydrologic budget was developed from data collected during monthly synoptic surveys conducted in the alluvial valleys. The effects of extended dry periods on the hydrology and water quality of both surface and ground water during 1989, and the potential effects of water use and water quality in the study area on the water resources of the Salinas alluvial fan were determined.

Throughout this report, the term "basins" will refer to the entire watersheds of both the Río Majada and the Río Lapa. The term "study area" will refer to the alluvial Río Majada and Río Lapa valleys from which surface water and ground water flow to the Salinas alluvial fan.

\section{Description of Study Area and Climate}

The Río Majada and Río Lapa basins are located in the south coast of Puerto Rico, 5 mi north-northeast of Salinas (fig. 1), and comprise a total area of about $36 \mathrm{mi}^{2}$. The study area is the $1.5 \mathrm{mi}^{2}$ of alluvial fill in the lower part of the basins. The study area is bounded by the alluvium-bedrock contact along the valley edges and at the southwestern edge of the Albergue Olímpico field. Two streams, the Río Majada and the Río Lapa, flow into the alluvial valleys from volcanic rocks to the north and northeast. The Río Lapa joins the Río Majada $1.7 \mathrm{mi}$ below the head of the alluvium in the Río Majada Valley. The streams, which drain part of the high-rainfall Cordillera Central, are perennial upstream of the study area at sites 1.2, and 3 (fig. 1), but are ephemeral within the study area. The land surface of the study area has an average slope of $40 \mathrm{ft} / \mathrm{mi}$.

Diversion canals from the Río Majada and the Río Lapa have supplied water for irrigation to several farms outside the 


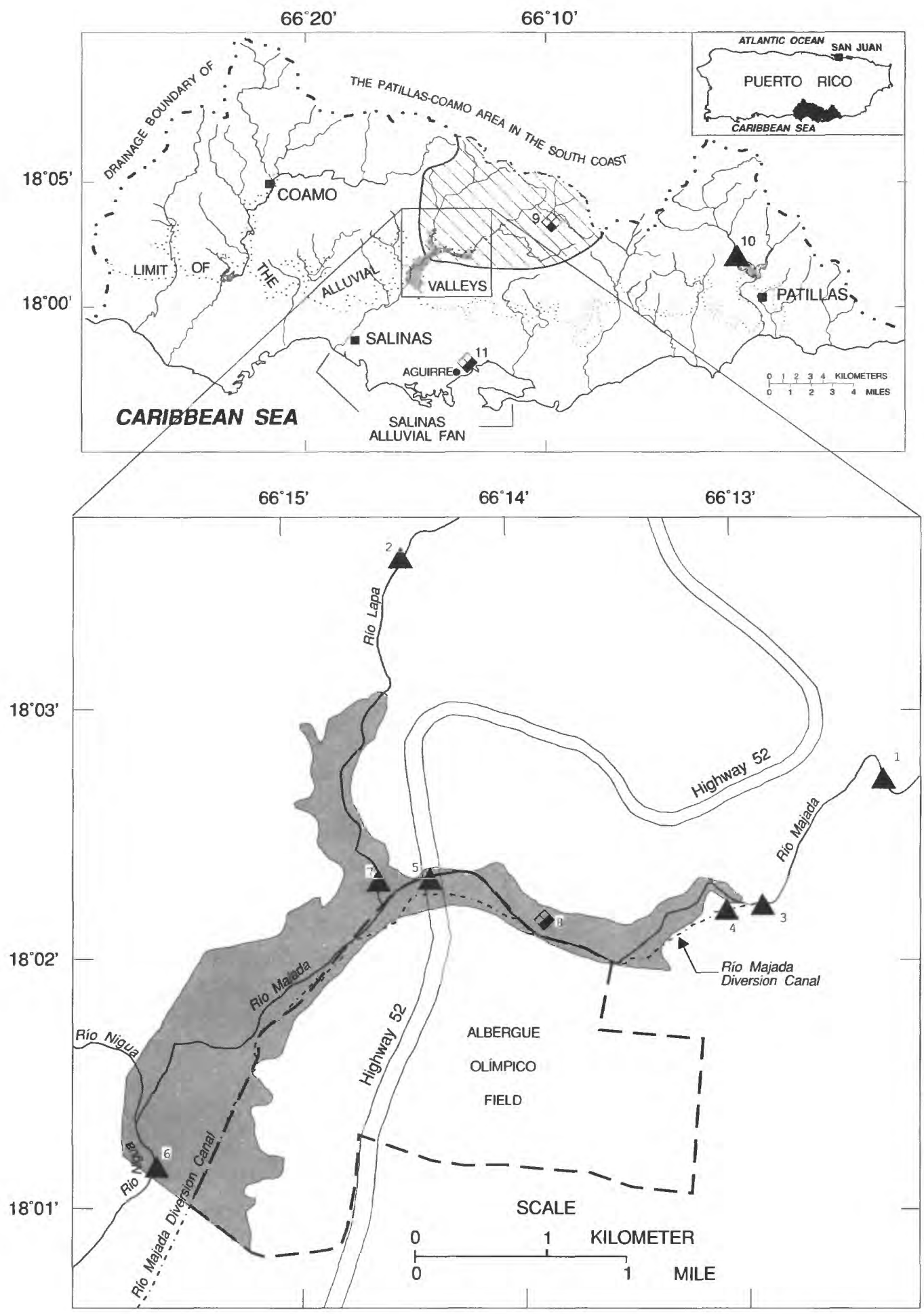

EXPLANATION

RIOO MAJADA AND RIOO LAPA BASINS

STUDY AREA

STREAM OR DIVERSION CANAL MEASURING SITE AND NUMBER

PAN EVAPORATION-RAINFALL STATION AND NUMBER

RAINFALL STATION IN RIOO MAJADA HEADWATERS AND NUMBER

Figure 1. Location of the Río Majada and Río Lapa basins, study area, and surface-water, pan evaporation-rainfall, and rainfall data-collection sites. 
study area since 1861 (McClymonds and Díaz, 1972). The Río Majada canal diverted as much as $8.7 \mathrm{ft}^{3} / \mathrm{s}$ from the Río Majada and the Río Lapa canal diverted as much as $4.9 \mathrm{ft}^{3} / \mathrm{s}$ from the Río Lapa. Records from 1908 to 1922 show that the annual flow in the canals averaged $4.8 \mathrm{ft}^{3} / \mathrm{s}$ (McClymonds and Díaz, 1972). The Río Lapa canal is no longer in use, but the Río Majada canal is still used.

The land within the Río Majada and Río Lapa basins is used for recreation and sport training, residential homes, agriculture (mostly livestock pasture), industry, military bases, and forests. Forests and agriculture are the major land-use categories in the basins. In the Río Majada basin, forests cover about 76 percent $\left(19 \mathrm{mi}^{2}\right)$ and agriculture about 10 percent $\left(2.5 \mathrm{mi}^{2}\right)$ of the entire basin $\left(25 \mathrm{mi}^{2}\right)$. In the Río Lapa basin, forests cover about 64 percent $\left(7 \mathrm{mi}^{2}\right)$ and agriculture about 21 percent $\left(2.3 \mathrm{mi}^{2}\right)$ of the entire basins $\left(11 \mathrm{mi}^{2}\right)$.

The land within the study area is mostly used for military and residential purposes. These uses cover about $1 \mathrm{mi}^{2}$ or about two-thirds of the alluvial valley area.

Climate of the study area is semi-arid, and is characterized by extensive dry periods, relatively low precipitation, and high rates of evapotranspiration. Along the edge of the coastal plain at Aguirre (site 11), about 6 mi southeast of the study area, the 30-year average rainfall is $45 \mathrm{in} / \mathrm{yr}$ and average pan evaporation is $81 \mathrm{in} / \mathrm{yr}$ (U.S. National Oceanic and Atmospheric Administration, 1982). Rainfall at site 9 , about 5 mi northeast of the study area, is greater, and averages $77 \mathrm{in} / \mathrm{yr}$ (U.S. National Oceanic and Atmospheric Administration, 1982). The meandaily water and air temperatures recorded in the study area (February to December 1989), as part of this investigation, were both $79^{\circ} \mathrm{F}$, and the water and air temperature differences between the hottest month (August) and the coolest month (January) of the year were both only $14^{\circ} \mathrm{F}$.

\section{Methods and Procedures}

In order to measure evaporation in the study area, a pan evaporation station (site 8 , fig. 1) was constructed according to the U.S. National Oceanic and Atmospheric Administration (NOAA) standards (U.S. Weather Bureau, 1970). The data that were collected daily consisted of total rainfall, total wind flow, total pan evaporation, and minimum and maximum ambient temperature of air and water. Graphic representations of the measured rainfall and pan evaporation in the study area and rainfall in adjacent areas are presented later in the report.

Surface-water stations were constructed in order to obtain continuous stage-discharge data at sites 1 and 2 (fig. 1 ) to assess the flow characteristics of the two streams in the basins and to determine streamflow into the study area. Data collection at these stations began on October 1988. Step-backwater analyses (Shearman and others, 1986) were conducted at the continuousrecording streamflow stations to define the stage-discharge rating curve. Discharge was measured on a monthly basis at the continuous-record (sites 1 and 2, fig. 1, table 1) and partialrecord stations (sites $3,5,6$, and 7 , fig. 1, table 1) to help define the interaction between the streams and the aquifer. Discharge was also measured at the Río Majada diversion canal at the head of the upper Río Majada Valley (site 4, fig. 1). Correlation analysis (Ezekiel and Fox, 1959) was made with the discharge data from the Río Majada continuous-recording station (site 1, fig. 1) and discharge data from the diversion canal (site 4, fig. 1) to estimate the total volume diverted through the canal. Regression analyses (Ezekiel and Fox, 1959) were conducted with the discharge data from a long-term continuous-record gaging station (site 10, fig. 1) outside of the basins and continuous-record gaging stations (site 1 and 2, fig. 1) within the basins to assess the effect of long-term (1967 to 1989) rainfall variation on the streamflow. The mean-monthly flows from January to December 1989 recorded at the stations were used in the analyses.

A well inventory was conducted and a monitoring network of 20 wells was developed (fig. 2 and table 1). Wellcompletion, water-level, specific-capacity, pumpage data, and drillers' lithologic descriptions were compiled for existing wells. In addition, information from 15 test holes (designated RM and RL, table 1) drilled as part of the investigation was also included in the database. These test holes were drilled using a dual-tube, open-center rotary auger. With this method, air or water circulates down between the inner and outer pipes of the drilling stem and returns to the surface through the inner pipe with the core samples. The cores were collected and stored for further description and for correlation with the seismicrefraction and electrical-resistivity data. The geophysical data and the well-lithologic descriptions are on file in the USGS, Caribbean District office. Twelve test holes were cased and screened at depths from 18 to $59 \mathrm{ft}$ below land surface and were used as observation wells.

Aquifer tests were conducted at the observation wells to estimate the aquifer hydraulic properties. Slug-injection tests were conducted at the observation wells, and the data were used to estimate hydraulic conductivity by the method developed by Bouwer and Rice (1976). Aquifer transmissivity was obtained by multiplying the hydraulic conductivity by the aquifer thickness at the observation well sites. Specific-capacity tests were conducted to obtain the transmissivity at sites 20 and 37 (fig. 2), and the data were analyzed by the method developed by Theis (1963). Five observation wells (sites 13, 29, 34, 36, and 45 ) were instrumented with automatic data recorders that 


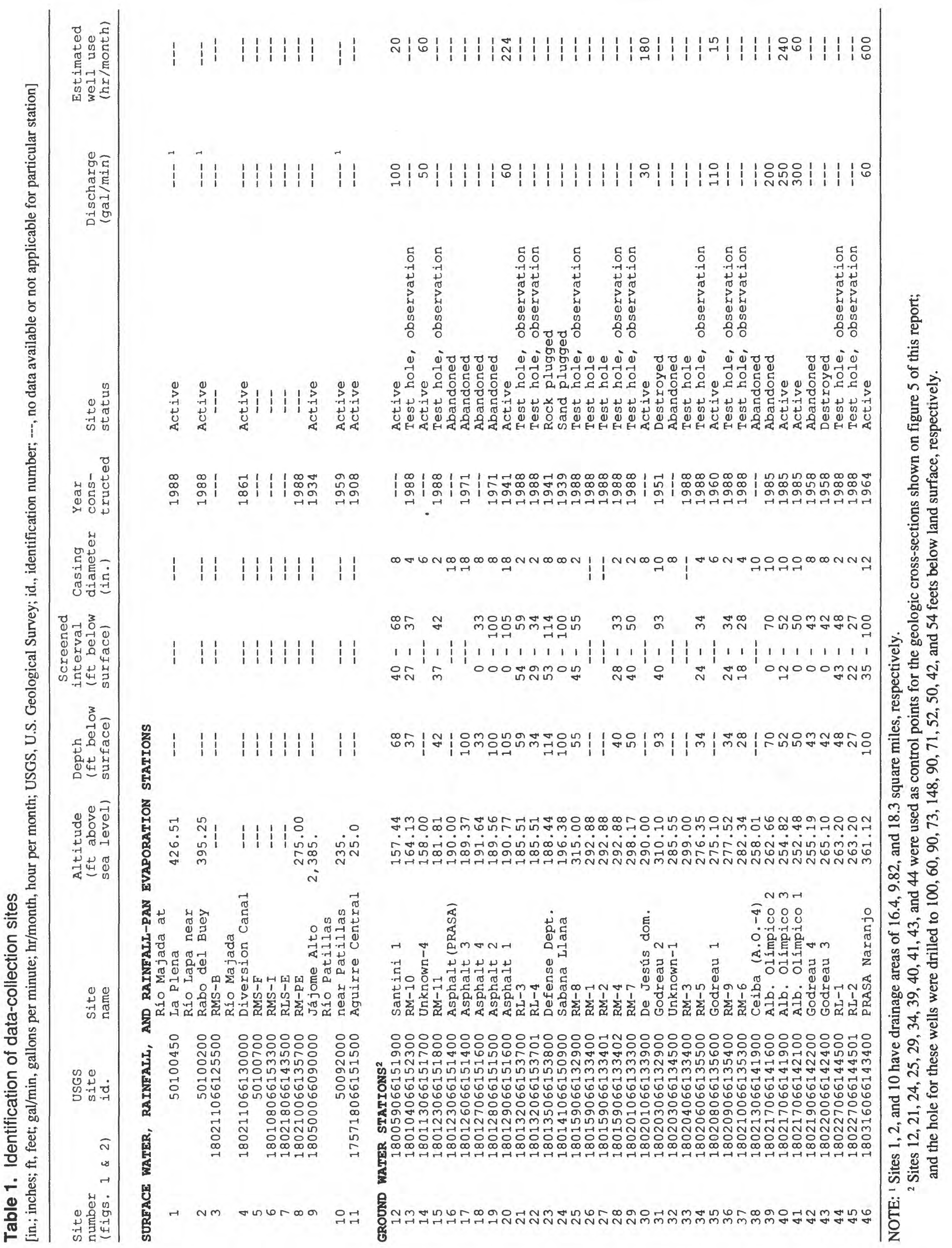




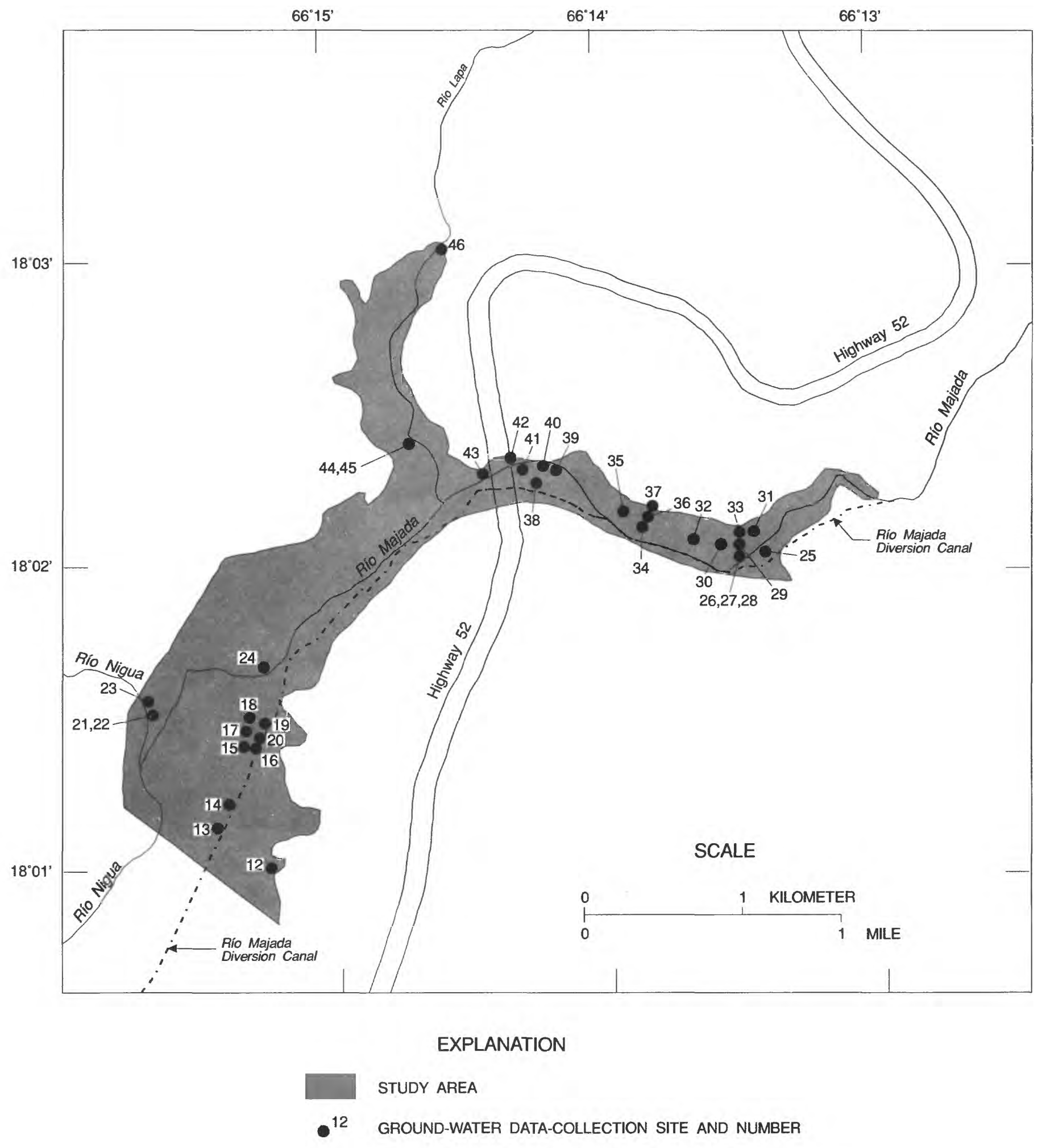

Figure 2. Location of ground-water data-collection sites. 
recorded water-level measurements at 15 -minute intervals. Water-levels were measured monthly at the remaining 12 observation wells and at 12 pre-existing wells. Elevations of pre-existing wells, test holes, observation wells, and selected stream-discharge stations were referenced to mean sea level.

Ground-water and surface-water samples were collected for analyses of common ions, fecal coliform and fecal streptococci bacteria, and volatile organic compounds (VOC) according to procedures outlined by Skougstad and others (1979) and by Britton and Greeson (1977). Chemical constituents were analyzed at the USGS National Water Quality Laboratory in Colorado. Bacteriological analyses were conducted by USGS personnel in Puerto Rico. The samples were collected on a monthly basis during 1989 at two stream sites (sites 1 and 2, fig. 1) and four production wells (sites 20,30, 40, and 46; fig. 2); however, no samples were collected during September 1989. At well site 40 , the water samples for fecal bacteria counts were collected before and after chlorine was injected to pumped water. At well site 46 , water samples were collected after the point of chlorine injection.

\section{Geology}

The surface geology of the Río Majada and Río Lapa basins consists of two major lithologic types (fig. 3). These units are the alluvial deposits of Quaternary age and the fractured volcanic rocks of Cretaceous and Tertiary ages (Berryhill and Glover, 1960; Glover, 1961 and 1971). Alluvial deposits, which are composed of unconsolidated sand, gravel, and angular to rounded boulders, range in thickness from as much as $30 \mathrm{ft}$ to a thin edge along the margins of the valleys (figs. 4 and 5). The alluvial deposits are underlain by highly-weathered volcanic rocks, which are sand-like in texture, and range in thickness from less than 10 to about $80 \mathrm{ft}$. This material is underlain by partly-weathered and unweathered indurated volcanic rocks composed of tuffaceous mudstone, pillow lava, conglomerates, volcanic breccia, and metamorphic volcanic rocks (Berryhill and Glover, 1960; Glover, 1961 and 1971).

The total combined thickness of both alluvial deposits and highly weathered rocks ranges from less than 10 to about $150 \mathrm{ft}$. These units are thickest in the upper Río Majada Valley. Their total combined thickness is no greater than about $70 \mathrm{ft}$ at the southern boundary of the study area.

\section{HYDROLOGY}

The hydrology of the study area is defined by the interaction of the surface-water and ground-water systems. The surface- water system includes two streams, the Río Majada and the Río Lapa. The ground-water system primarily consists of a shallow water-table aquifer, contained in both alluvial deposits and highly-weathered volcanic rocks. The unweathered volcanic rocks in the study area may also contain some ground water in fractures and fault zones. These zones are much less important than the shallow aquifer in the study area because of low yields to wells, but may be important sources of ground water in the upper part of the basins.

The water budget of the shallow aquifer is affected by recharge from streamflow and rainfall, and by discharge through pumpage and evapotranspiration. All the components of the water budget were estimated by various methods described in subsequent sections, and the data are shown on figures 6 to 12 and tables 2 to 4 . These components are used to construct hydrologic budgets for the overall system and for the ground-water system (table 5) in the study area.

\section{Rainfall and Evapotranspiration}

Rain fell in the study area (site 8, fig. 1) on 80 days from February to December 1989. Rainfall ranged from 0.01 to 1.33 in. per day, from 0.06 to 7.57 in. per month, and totaled about 16.5 in. from February to December, 1989 (fig. 6a). The 16.5 in. of rainfall in the study area during the 11 months of 1989 was assumed as the total for the entire year because January in the south coast is usually a dry month, or one with very low rainfall. Rainfall (12 months) in the headwaters of the Rio Majada (site 9) occurred on 182 days, ranged from 0.01 to 6.32 in. per day, from 0.50 to 14.9 in. per month, and totaled $50.3 \mathrm{in}$. in 1989 (fig. 6b). Rainfall in the headwaters was 35 percent less than the 1951-80 annual average of 77.2 in. (site 9), but still about 3 times higher than rainfall in the study area (site 8) during 1989.

Pan evaporation rates in the study area (site 8) ranged from about 0.10 to 0.47 in. per day, from 4.70 to 8.15 in. per month, and totaled 70.1 in. from February to December 1989. The total pan evaporation during the 11 months of 1989 was 4.2 times higher than rainfall (fig. 6c) in the study area. Pan evaporation averaged about 0.2 in. per day for February to December, 1989. Daily rainfall exceeded daily pan evaporation rates on only 25 of the 335 days monitored. Evapotranspiration is a process difficult to measure or quantify; however, estimates were made based on a water-balance analysis that is discussed in the 'Hydrologic Budget' section of this report. 


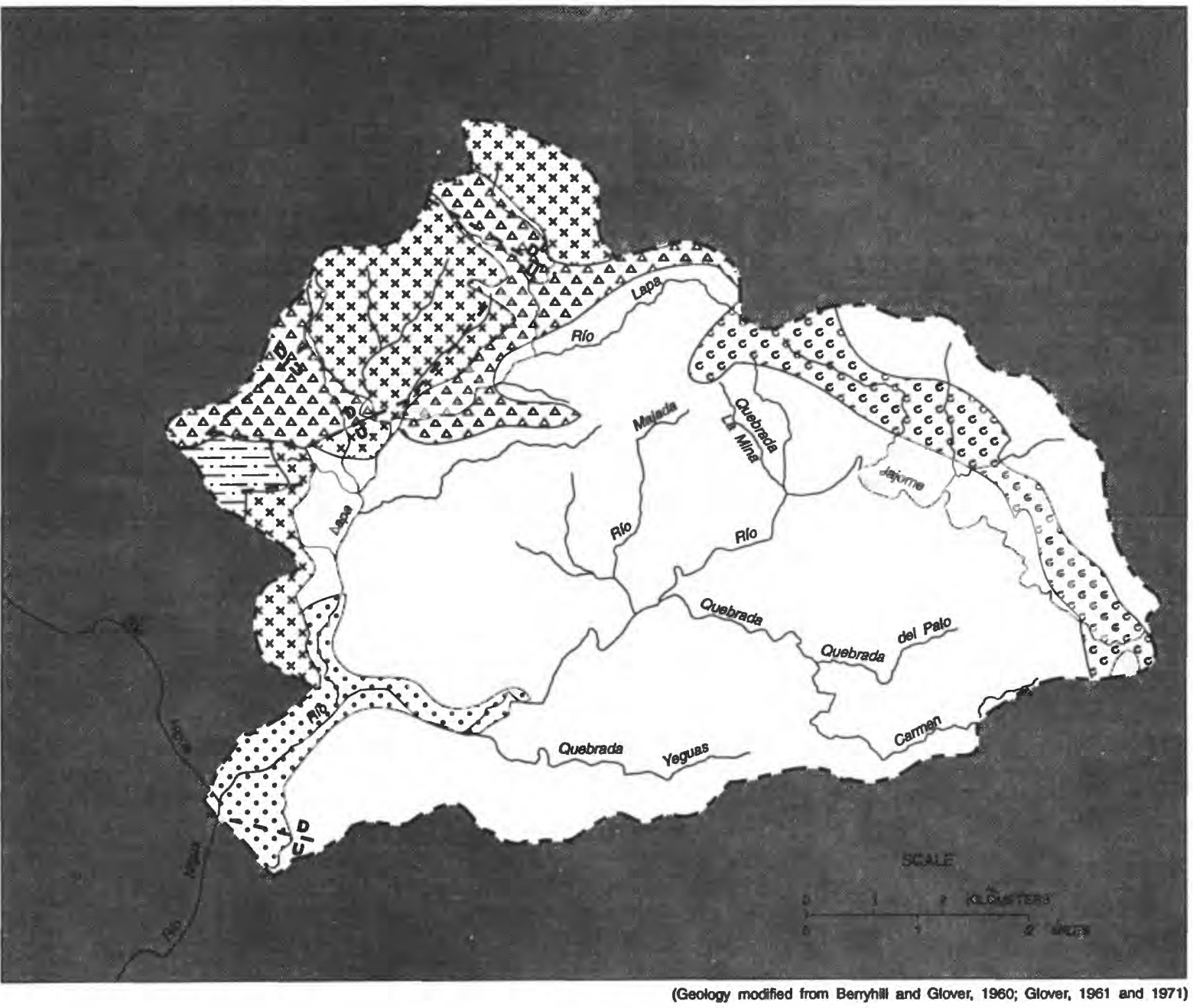

\section{EXPLANATION}

QUATERNARY

\section{$\because \because \because$ Alluvium}

\section{TERTIARY}

e $e^{e} e^{e} e^{e} e^{e}$ Metamorphic volcanic rocks

\begin{tabular}{l} 
CRETACEOUS \\
Tuffaceous mudstone \\
\hline \\
\hline
\end{tabular}

- - - - - Río MAJADA-Río LAPA BASINS BOUNDARY

- - - $\frac{D}{U}$ - - FAULT. $U$ is upthrown and $D$ is downthrown side of fault.

Figure 3. Generalized geology of the Río Majada and Río Lapa basins. 

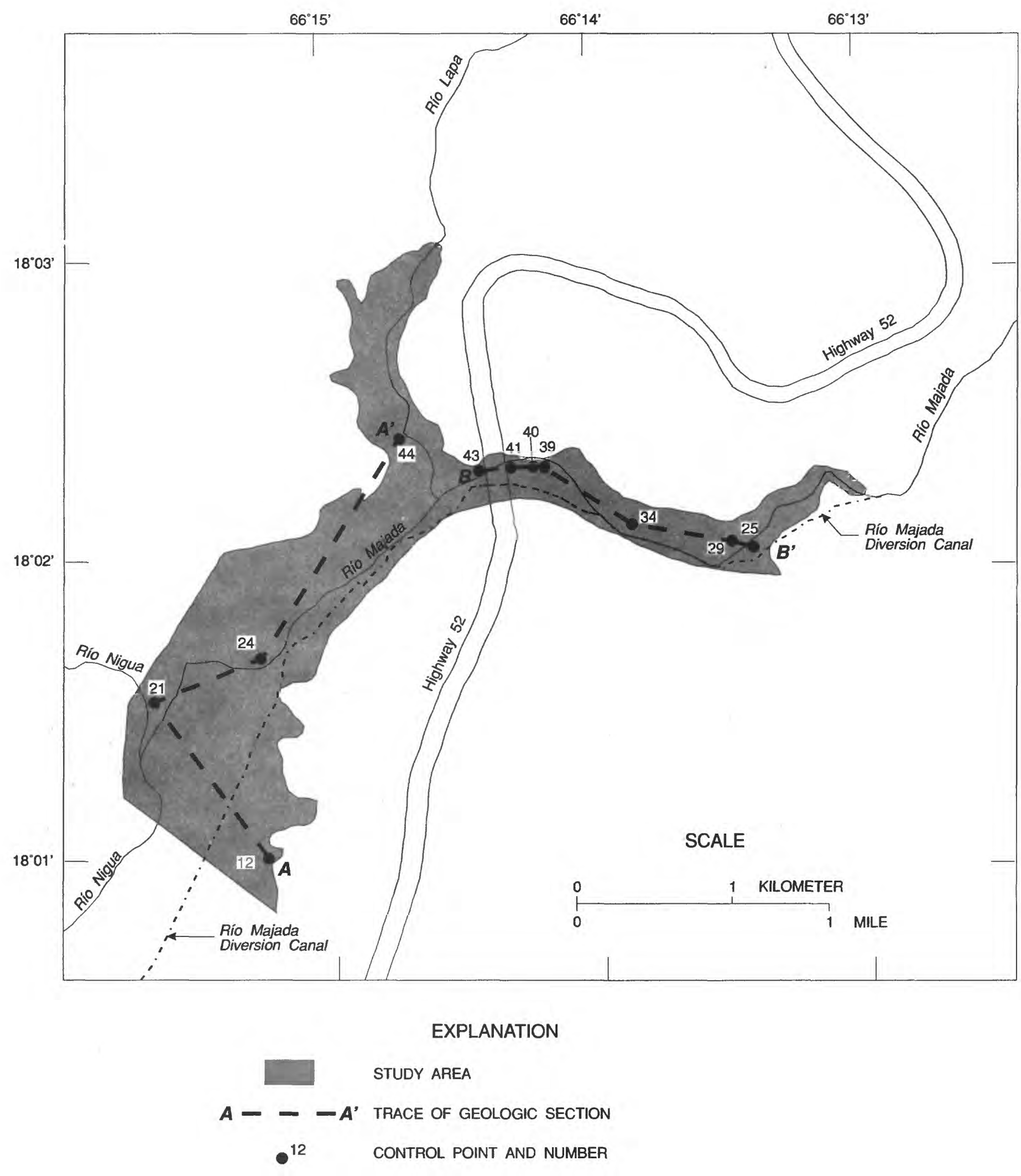

Figure 4. Location of geologic sections A-A' and B-B' and control points in the study area. 


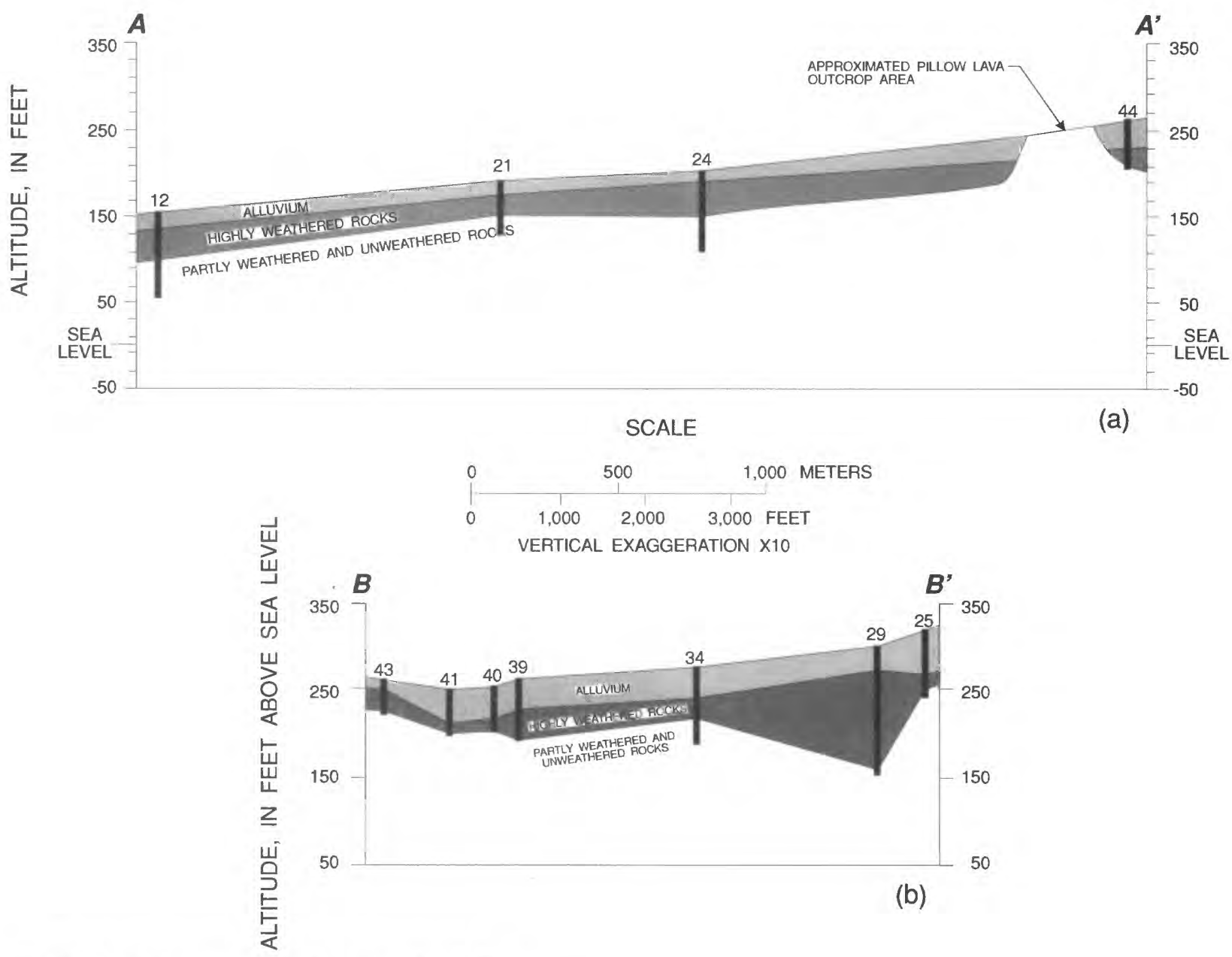

Figure 5. Geologic sections (a) A-A' and (b) B-B'.

\section{Surface-Water Resources}

Surface-water features in the study area include two streams, the Río Majada and the Río Lapa, which have drainage areas at gaging stations of 16.4 and $9.82 \mathrm{mi}^{2}$, respectively. A brick and concrete irrigation canal upstream of the alluvium in the Río Majada Valley (at site 4, fig. 1) diverts water from the stream for agricultural use outside the study area.

Streamflow varied seasonally in response to rainfall in the basins. Baseflow recession during 1989 occurred from January to August and the lowest flows occurred during July and August (fig. 7). Streamflow increased from September to October, when most of the rainfall occurred in the basins. The average streamflow recession for both streams was $0.01 \mathrm{ft}^{3} / \mathrm{s}$ per day from January to August 1989.

The flow at the Río Lapa gaging station (site 2) during 1989 was 1.05 times the flow at the Río Majada gaging station (site 1). Most of the flow from the Río Majada and the Río Lapa, which occurred during the wet season, flowed out of the study area. Mean-monthly flows in 1989 ranged from $0.62 \mathrm{ft}^{3} / \mathrm{s}$ to
$30.1 \mathrm{ft}^{3} / \mathrm{s}$ (38.0 to 1,790 acre- $\mathrm{ft}$ ) for the Río Majada and from $0.14 \mathrm{ft}^{3} / \mathrm{s}$ to $29.1 \mathrm{ft}^{3} / \mathrm{s}$ ( 8.40 to 1,730 acre-ft) for the Río Lapa. The flows at the Río Majada and Río Lapa gaging stations during 1989 averaged $4.13 \mathrm{ft}^{3} / \mathrm{s}\left(2,990\right.$ acre-ft/yr) and $4.32 \mathrm{ft}^{3} / \mathrm{s}$ (3,130 acre-ft/yr), respectively.

Flow in the Río Majada was about 3 times the flow in the Río Lapa recorded at gaging stations during predominantly low-flow periods between January to August 1989. During this period, the average flow at the Río Majada gaging station was $1.7 \mathrm{ft}^{3} / \mathrm{s}$ (816 acre-ft), and at the Río Lapa gaging station flow was $0.61 \mathrm{ft}^{3} / \mathrm{s}$ (287 acre-ft). The significant difference in average discharges between the Río Majada and the Río Lapa during the dry season contrast with the mean-annual discharge. This could indicate that the weathered part of the volcanic rocks within the Río Majada watershed stores more water during rainfall events and releases it more slowly, which enables the stream to sustain a higher flow during the dry season. The difference in discharge may also be because the drainage area of the Río Lapa at site 2 is $6.58 \mathrm{mi}^{2}$ smaller than that of the Río Majada at site 1, which assuming the volume of weathered rock is proportional, allows less water to be stored in the Río Lapa basin. 

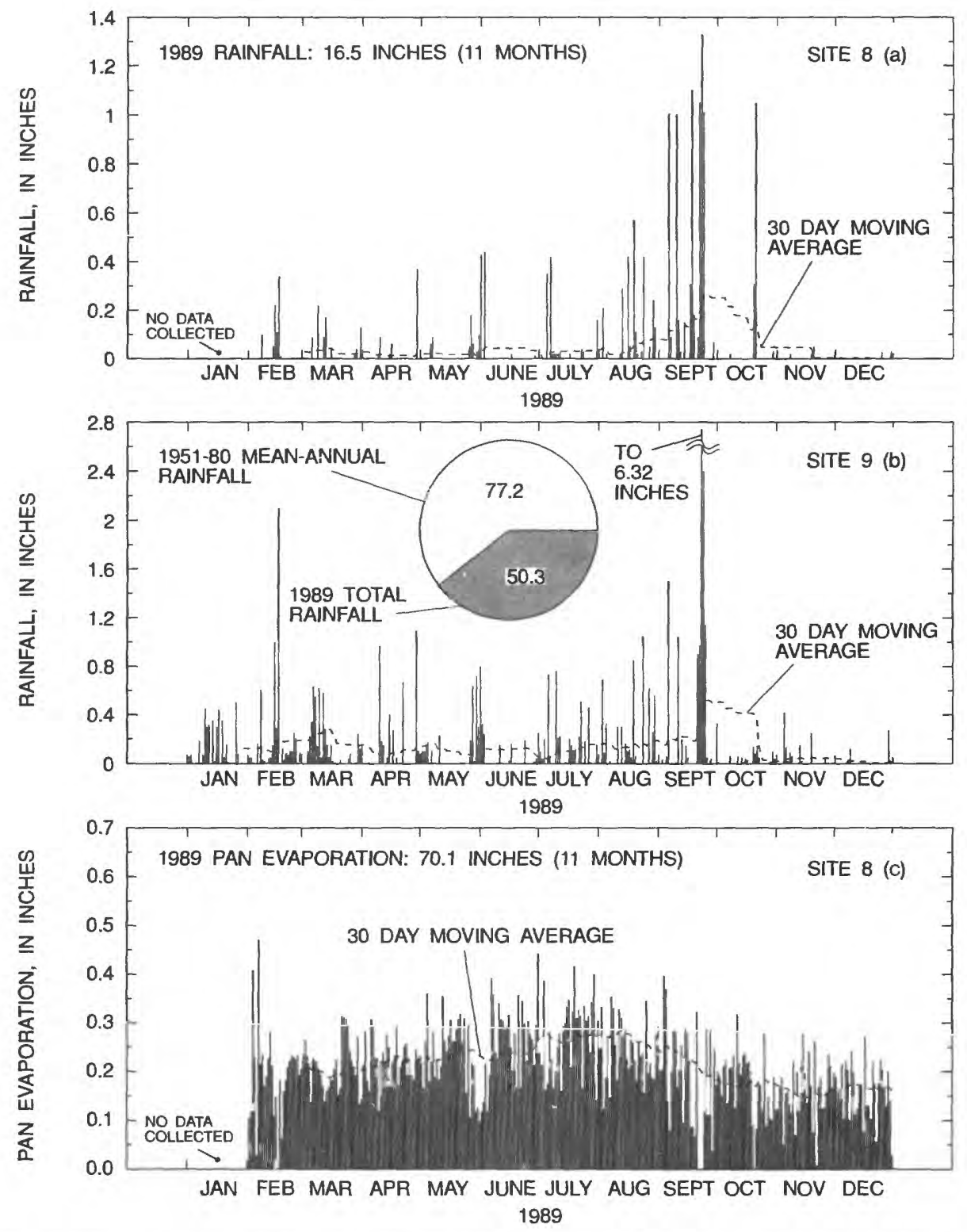

Figure 6. Rainfall in the (a) study area, (b) Río Majada headwaters, and (c) pan evaporation in the study area.

During the dry season, about 40 percent of the flow in the Río Majada was diverted at the irrigation canal (site 4, fig. 1). The average flow that was diverted from the Río Majada to out of the study area from the Río Majada was estimated to be 0.68 $\mathrm{ft}^{3} / \mathrm{s}$ ( 330 acre- $\mathrm{ft} / \mathrm{yr}$ ) during January to August 1989 . Only about 60 percent of the flow of the Río Majada during this period, therefore, was available for recharge to the alluvial aquifer. The estimated average diverted flow from the Río Majada during January to August 1989 is equivalent to the flow diverted for the entire year (1989) because the irrigation canal was plugged with debris from September to December 1989 as a result of damage caused by Hurricane Hugo, which hit Puerto Rico on September 18,1989 . The estimated amount of flow at the diversion canal is conservative because it is based on a correlation analysis (Searcy, 1959) of instantaneous monthly flow measurements at the Río Majada gaging station and the diversion canal partial-record station. This analysis showed a correlation coefficient $(r)$ of 0.84 . The correlation was constrained to measured base flows that ranged from 0.47 to $2.26 \mathrm{ft}^{3} / \mathrm{s}$, and the equation obtained for site 1 (fig. 1) was applied to the flows recorded at this site for the same period and between the constrained values. The equation that defines this correlation is $\mathrm{Y}=(0.48) \mathrm{X}^{1.06}$, where ' $\mathrm{Y}$ ' is the estimated flow diverted, in $\mathrm{ft}^{3} / \mathrm{s}$, and ' $\mathrm{X}$ ' is the discharge at gaging station (site 1 ), in $\mathrm{ft}^{3} / \mathrm{s}$. For those mean-daily discharges that were greater than the maximum constrained value of $2.26 \mathrm{ft}^{3} / \mathrm{s}$, a flow of $1.16 \mathrm{ft}^{3} / \mathrm{s}$ was assumed to be the maximum flow diverted through the canal. Therefore, the estimated amount of flow is conservative. 


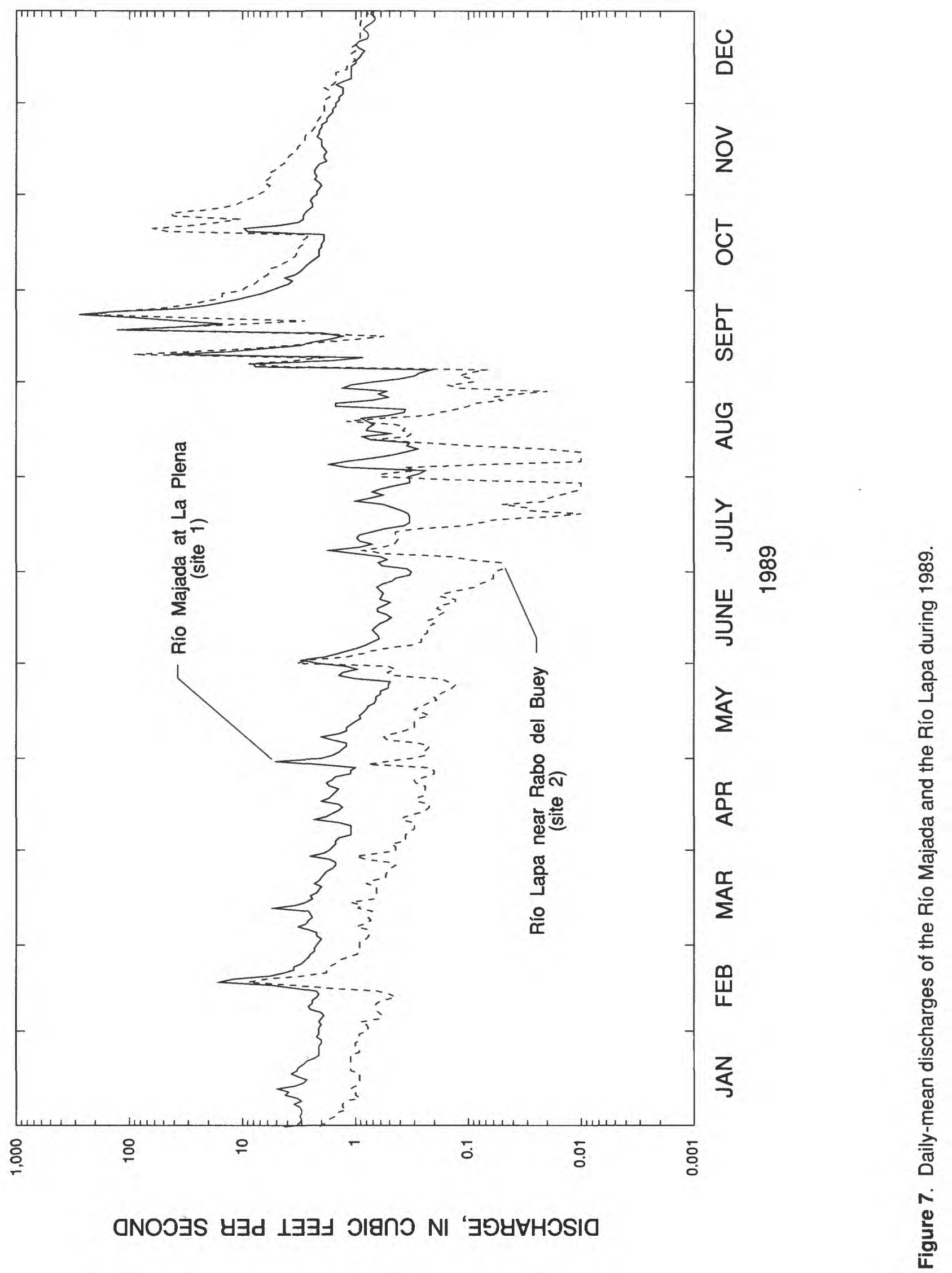


Streamflow seepage surveys indicated flow infiltration rates as high as $0.60,1.28$, and $2.55 \mathrm{ft}^{3} / \mathrm{s}$ per mi for the upper (upstream of site 5) and lower (downstream of site 5) sections of the alluvial reach of the Río Majada, and the alluvial reach of the Río Lapa, respectively (table 2). These rates were computed as the difference between measured flows entering and leaving the selected reaches divided by the section lengths. Monthly streamflow seepage surveys conducted during 1989 indicate that flow equal to or less than $1.08 \mathrm{ft}^{3} / \mathrm{s}$ and $2.56 \mathrm{ft}^{3} / \mathrm{s}$ entering the upper and the lower Río Majada alluvial reaches, respectively, may seep completely into the aquifer. Flows equal to or less than $2.80 \mathrm{ft}^{3} / \mathrm{s}$ entering the Río Lapa alluvial reach may seep completely into the aquifer in the Río Lapa Valley.

Both the Río Majada and the Río Lapa are dry most of the year at their confluence, and streamflow out of the study area in 1989 occurred only during the high flows of September and October (Ramos-Ginés, 1991). The streamflow seepage surveys at site 5 (fig. 1) indicated no flow from April to August 1989. At site 7, the streamflow seepage surveys indicated no flow from January to August 1989.

Measured flow at the lower reach of the Río Majada (site 6) was $2.20 \mathrm{ft}^{3} / \mathrm{s}$ during a survey conducted on October 18, 1989 (Ramos-Ginés, 1991). The incoming streamflow to the study area, from the Río Majada (flow at site 3) and the Río Lapa (site 2), averaged $7.42 \mathrm{ft}^{3} / \mathrm{s}$ during the same day, indicating a loss of $5.22 \mathrm{ft}^{3} / \mathrm{s}$ to the alluvial aquifer and to evapotranspiration. During the months of September and October, flows averaged 16.7 and $21.1 \mathrm{ft}^{3} / \mathrm{s}(1,990$ and 2,540 acre-ft) for the Río Majada (site 1, fig. 7) and the Río Lapa (site 2, fig.7), respectively.

Flow out of the study area during the wet season of 1989 was estimated to be 3,900 acre-ft. This estimate was computed by subtracting the estimated aquifer recharge by streamflow seepage ( 630 acre-ft) from the total combined flow $(4,530$

Table 2. Infiltration rates based on streamflow discharge measurements conducted from December 1988 to December 1989

\begin{tabular}{|c|c|c|c|c|}
\hline \multirow[b]{2}{*}{$\begin{array}{c}\text { Date of } \\
\text { survey } \\
\text { (Year-Month) }\end{array}$} & \multicolumn{3}{|c|}{ Discharge, in cubic feet per second } & \multirow[b]{2}{*}{$\begin{array}{l}\text { Infiltration rate, in } \\
\text { cubic feet per second } \\
\text { per mile }\end{array}$} \\
\hline & $\begin{array}{l}\text { Head of } \\
\text { reach on } \\
\text { alluvium }\end{array}$ & $\begin{array}{l}\text { Lower end of } \\
\text { reach on } \\
\text { alluvium }\end{array}$ & Change & \\
\hline \multicolumn{5}{|c|}{ (Section length is 1.8 miles) } \\
\hline $88-12$ & 2.63 & 2.56 & 0.07 & 0.04 \\
\hline $89-01$ & 2.18 & 1.10 & 1.08 & 0.60 \\
\hline 89-02 & 0.48 & 0.34 & 0.14 & 0.08 \\
\hline $89-03$ & 1.07 & 0.51 & 0.56 & 0.31 \\
\hline $89-04$ & 0.27 & 0 & 0.27 & 0.15 \\
\hline 89-05 & 0.26 & 0 & 0.26 & 0.14 \\
\hline $89-06$ & 0.10 & 0 & 0.10 & 0.06 \\
\hline $89-07$ & 0.26 & 0 & 0.26 & 0.14 \\
\hline $89-08$ & 0.21 & 0 & 0.21 & 0.12 \\
\hline $89-10$ & 4.48 & 3.82 & 0.66 & 0.37 \\
\hline $89-11$ & 1.76 & 1.59 & 0.17 & 0.09 \\
\hline $89-12$ & 1.49 & 1.21 & 0.28 & 0.16 \\
\hline Lower Río Majada & \multicolumn{4}{|c|}{ (Section length is 2.0 miles) } \\
\hline $88-12$ & 2.56 & 0 & 2.56 & 1.28 \\
\hline $89-01$ & 1.10 & 0 & 1.10 & 0.55 \\
\hline 89-02 & 0.34 & 0 & 0.34 & 0.17 \\
\hline $89-03$ & 0.51 & 0 & 0.51 & 0.26 \\
\hline $89-10$ & 4.34 & 2.20 & 2.14 & 1.07 \\
\hline $89-11$ & 1.59 & 0 & 1.59 & 0.80 \\
\hline $89-12$ & 1.21 & 0 & 1.21 & 0.61 \\
\hline Río Lapa & \multicolumn{4}{|c|}{ (Section length is 1.1 miles) } \\
\hline $88-12$ & 1.82 & 0 & 1.82 & 1.65 \\
\hline $89-01$ & 0.91 & 0 & 0.91 & 0.82 \\
\hline $89-02$ & 0.95 & 0 & 0.95 & 0.86 \\
\hline $89-03$ & 0.72 & 0 & 0.72 & 0.65 \\
\hline 89-04 & 0.22 & 0 & 0.22 & 0.20 \\
\hline $89-05$ & 0.27 & 0 & 0.27 & 0.25 \\
\hline $89-06$ & 0.24 & 0 & 0.24 & 0.22 \\
\hline $89-07$ & 0.06 & 0 & 0.06 & 0.05 \\
\hline 89-08 & 0.22 & 0 & 0.22 & 0.20 \\
\hline $89-10$ & 2.94 & 0.52 & 2.42 & 2.20 \\
\hline $89-11$ & 2.80 & 0 & 2.80 & 2.55 \\
\hline $89-12$ & 2.77 & 0 & 2.77 & 2.52 \\
\hline
\end{tabular}


acre-ft) from the Río Majada (2,540 acre-ft) and the Río Lapa $(1,990$ acre- $\mathrm{ft})$. This estimate is the amount of surface-water flow to the Salinas alluvial fan, and should be considered conservative since the computation assumes that the streams lost about $5.22 \mathrm{ft}^{3} / \mathrm{s}$ during September and October 1989.

\section{Low Flow}

The 60-day low flow for the Río Majada and the Río Lapa at the gaging stations (site 1 and 2) may be as low as 0.2 and 0.04 $\mathrm{ft}^{3} / \mathrm{s}$ every 10 years, respectively, as estimated from low-flow frequency analysis (Riggs, 1972) at the Río Patillas near Patillas gaging station (site 10, fig. 1). The 60-day low flow during 1989 for streams in the study area were as low as $0.60 \mathrm{ft}^{3} / \mathrm{s}$ for the Río Majada and $0.13 \mathrm{ft}^{3} / \mathrm{s}$ for the Río Lapa (fig. 8 and table 3 ), both flows had an estimated recurrence interval of about 2 years. The predicted low flow provides an important factor for water-resources planning and management and indicates the minimum estimated flow at gaging stations (site 1 and 2, fig. 1) that will probably be diverted, transpired, and infiltrated to the aquifer. The estimate is based on regression analyses (Ezekiel and Fox, 1959) made using the mean-monthly flow data at gaging stations (sites 1 and 2, fig. 1) and mean-monthly flow at the Río Patillas (site 10, fig. 1) during 1989. The analyses were constrained to the minimum and maximum mean-monthly values observed during 1989 . The minimum mean-monthly values that constrained the applicability of the regression analyses were $0.62 \mathrm{ft}^{3} / \mathrm{s}$ for the Río Majada (site 1) and 0.14 $\mathrm{ft}^{3} / \mathrm{s}$ for the Río Lapa (site 2), and the maximum mean-monthly values were $30.1 \mathrm{ft}^{3} / \mathrm{s}$ for the Río Majada and $29.1 \mathrm{ft}^{3} / \mathrm{s}$ for the Río Lapa. The regression coefficients (r) obtained were 0.93 and 0.92 for the Río Majada (site 1) and the Río Lapa (site 2), respectively.

Table 3. Low flows for the Río Majada and Río Lapa gaging stations during 1989

Low flow, in cubic feet per second

Length (days) Río Majada (site 1) Río Lapa (site 2)

$\begin{array}{rll}7 & 0.37 & 0.07 \\ 14 & 0.50 & 0.08 \\ 30 & 0.55 & 0.10 \\ 60 & 0.60 & 0.13 \\ 90 & 0.63 & 0.16 \\ 120 & 0.74 & 0.25 \\ 183 & 1.10 & 0.35\end{array}$
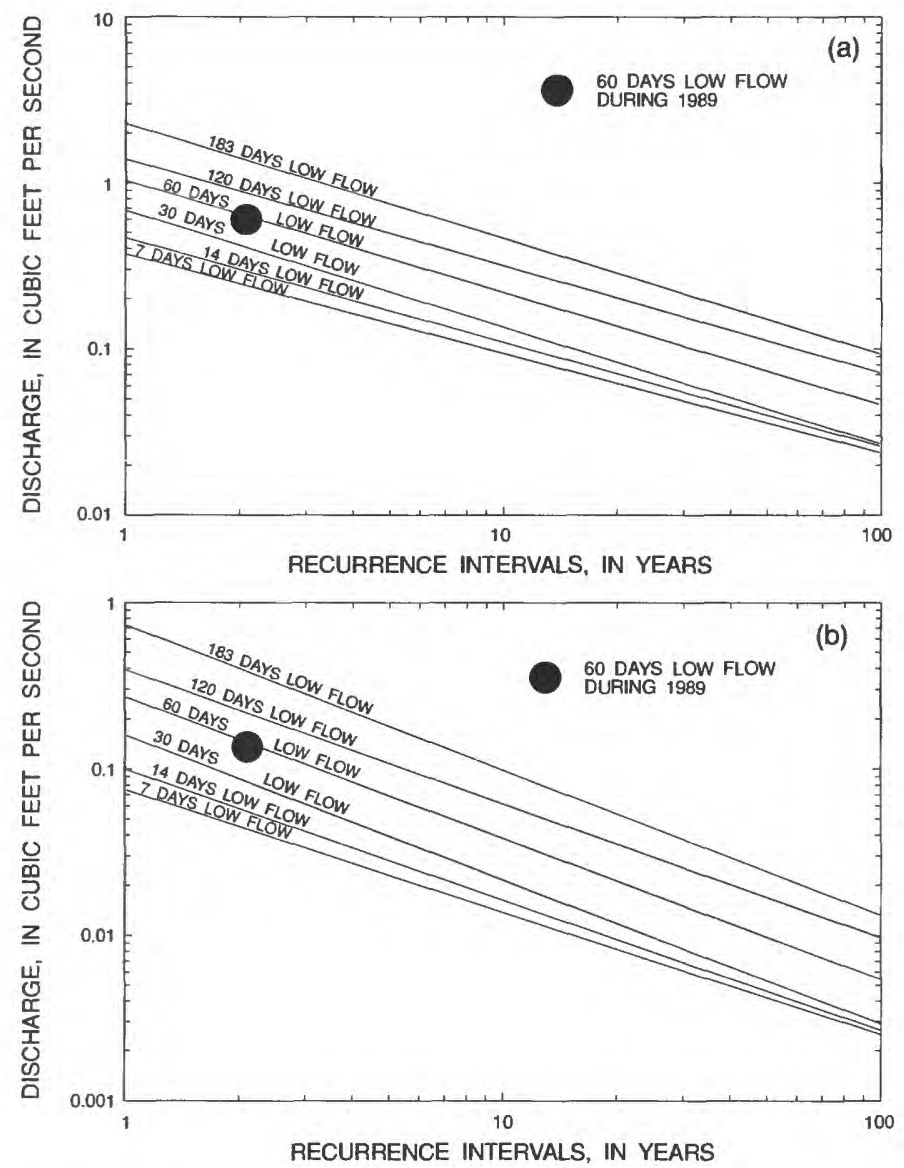

Figure 8. Low-flow frequency curves for the (a) Río Majada at La Plena (site 1) and (b) Río Lapas near Rabo del Buey (site 2) as estimated from the Río Patillas near Patillas (site 10) long-term recording station.

\section{Peak Discharges}

Floods that overtop the Río Majada and Río Lapa banks are fairly common, but floods did not occur during 1989. The area below the confluence of the streams has the greatest susceptibility to flooding, and floods may occur, on the average, about every 10 years (Haire, 1971 and 1972). Peak discharges recorded at sites 1 and 2 during 1989 were as much as 886 and $529 \mathrm{ft}^{3} / \mathrm{s}$ for the Río Majada and the Río Lapa, respectively, and occurred on September 23, 1989 when 6.32 in. of rain fell on the headwaters. These discharges did not overflow the river banks.

Peak discharges recorded in the Río Majada and the Río Lapa during major floods in southern Puerto Rico have been in the range of 7,300 to $13,000 \mathrm{ft}^{3} / \mathrm{s}$. The first documented flood occurred on September 6, 1960 and the peak discharge of the Río Majada at Highway 52 was $11,000 \mathrm{ft}^{3} / \mathrm{s}$. This flood, 
produced by a total of $11.83 \mathrm{in}$. of rainfall, is the largest measured since 1954, but local residents report that the 1928 and 1933 floods were larger (McClymonds and Díaz, 1972). Peak discharge recorded for the Río Majada was $13,000 \mathrm{ft}^{3} / \mathrm{s}$ measured at Highway 52 (site 5 ), and $7,300 \mathrm{ft}^{3} / \mathrm{s}$ for site 2 (Haire, 1972, p. 25) as a result of 35.75 in. of rain that fell during the floods of October 5 to 10, 1970. The recurrence intervals defined for both 1970 peaks were 8.5 and 7.5 years for the Río Majada and the Río Lapa, respectively.

\section{Ground-Water Resources}

Ground water in the study area occurs under water-table conditions in two different, but hydraulically connected, hydrogeologic units: in alluvial deposits and in highlyweathered volcanic rocks. The aquifer comprises both units and is bounded at the bottom and at valley edges by partially weathered and unweathered volcanic rocks. Average depths to water range from about $12 \mathrm{ft}$ below land surface in the upper valley areas to about $30 \mathrm{ft}$ below land surface in the southernmost part of the study area.

Ground water in the study area is used for recreationalinstitutional, livestock, industrial, and domestic uses. Pumping rates for industry, domestic use, and the Albergue Olímpico (recreational-institutional use), obtained from flow measurements and data compiled from farmer's records, range from 10 to $300 \mathrm{gal} / \mathrm{min}$. Total estimated pumpage was $0.29 \mathrm{Mgal} / \mathrm{d}$ (330 acre-ft/yr) in 1989. Water-supply withdrawals at the Albergue Olímpico constitute about 55 percent of all ground water used in the study area (fig. 9).

Hydraulic-conductivity values range from 7 to $140 \mathrm{ft} / \mathrm{d}$ (table 4) and generally increase toward the southwestern studyarea boundary. The apparent range of hydraulic conductivity values for the highly weathered part of the volcanic rocks is 7 to $14 \mathrm{ft} / \mathrm{d}$. These values were estimated from slug-injection tests conducted at eight sites using the method developed by Bouwer and Rice (1976), and by dividing the estimated transmissivity from specific-capacity tests conducted at two sites, using the method developed by Theis (1963), by the aquifer saturated thickness at these sites.

Aquifer transmissivity values, calculated by multiplying the hydraulic conductivity (from slug-injection tests) by the aquifer thickness and values obtained from specific-capacity tests, range from 180 to $4,000 \mathrm{ft}^{2} / \mathrm{d}$. Aquifer transmissivity values were higher in the upper Río Majada Valley where the aquifer thickness is greatest, and in the southwestern boundary area, where the aquifer hydraulic conductivity is highest. Values for specific yield or storage coefficient were not obtained in this study, but probably are about 0.15 in the alluvial deposits and

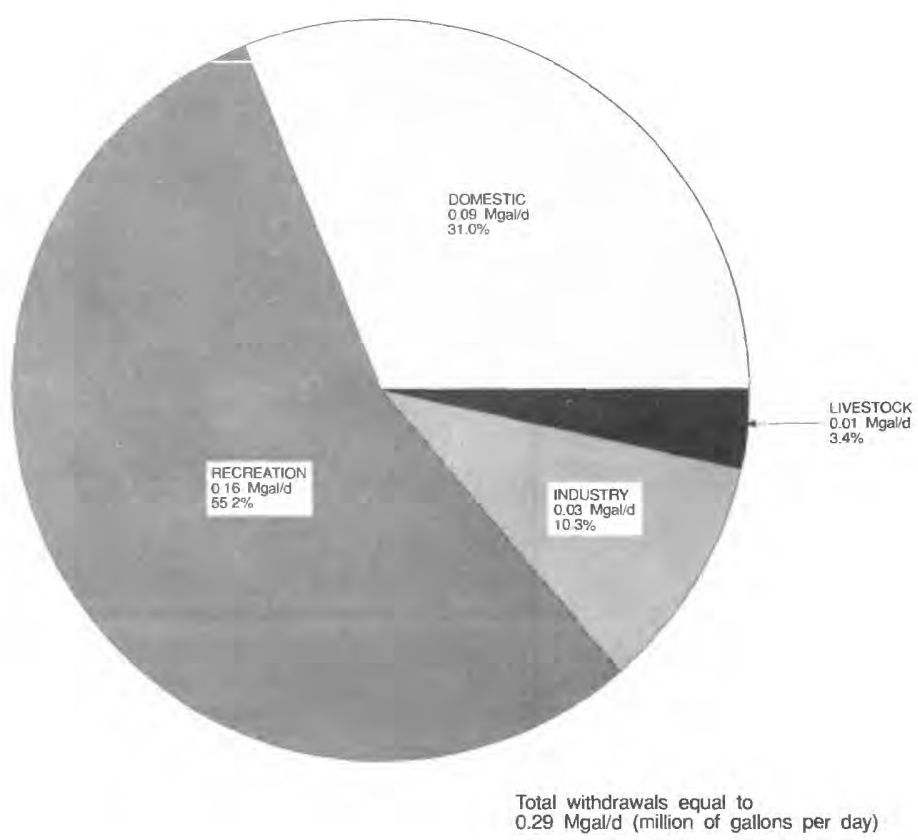

Figure 9. Ground-water uses and amount withdrawn in the study area in 1989.

0.25 in the highly weathered volcanic rocks (Morris and Johnson, 1967). A specific yield of 0.15 in alluvial deposits in the south coast was estimated by Giusti (1971a, b).

The water-table configuration was delineated for the hydrologic conditions of July and October (fig. 10), which represent the minimum and maximum water-level conditions measured in 1989, respectively. Ground water flows west in the upper Río Majada Valley, south in the Río Lapa Valley, and southwest in the lower Rio Majada Valley, following the general configuration of the land surface. The average hydraulic gradient in the aquifer was $50 \mathrm{ft} / \mathrm{mi}(0.01 \mathrm{ft} / \mathrm{ft})$. The hydraulic gradient, obtained from monthly ground-water level surveys, varied from 37 to $42 \mathrm{ft} / \mathrm{mi}(0.007$ to $0.008 \mathrm{ft} / \mathrm{ft})$ at the upper Río Majada Valley, from 46 to $52 \mathrm{ft} / \mathrm{mi}(0.009$ to $0.01 \mathrm{ft} / \mathrm{ft})$ at the lower part of the Río Majada Valley, and from 50 to $83 \mathrm{ft} / \mathrm{mi}(0.009$ to $0.016 \mathrm{ft} / \mathrm{ft}$ ) at the Río Lapa Valley during 1989.

The water-table declined about $4 \mathrm{ft}$ in the upper part of the Río Majada Valley, $12 \mathrm{ft}$ in the Río Lapa Valley, and $9 \mathrm{ft}$ in the lower Río Majada Valley from January to August 1989. Water levels in observation wells declined by $0.03 \mathrm{ft} / \mathrm{d}$ for the same period at wells in the upper and lower parts of the Río Majada Valley. Water levels in the Río Lapa Valley declined by 0.05 $\mathrm{ft} / \mathrm{d}$ for the same period (fig. 11). 


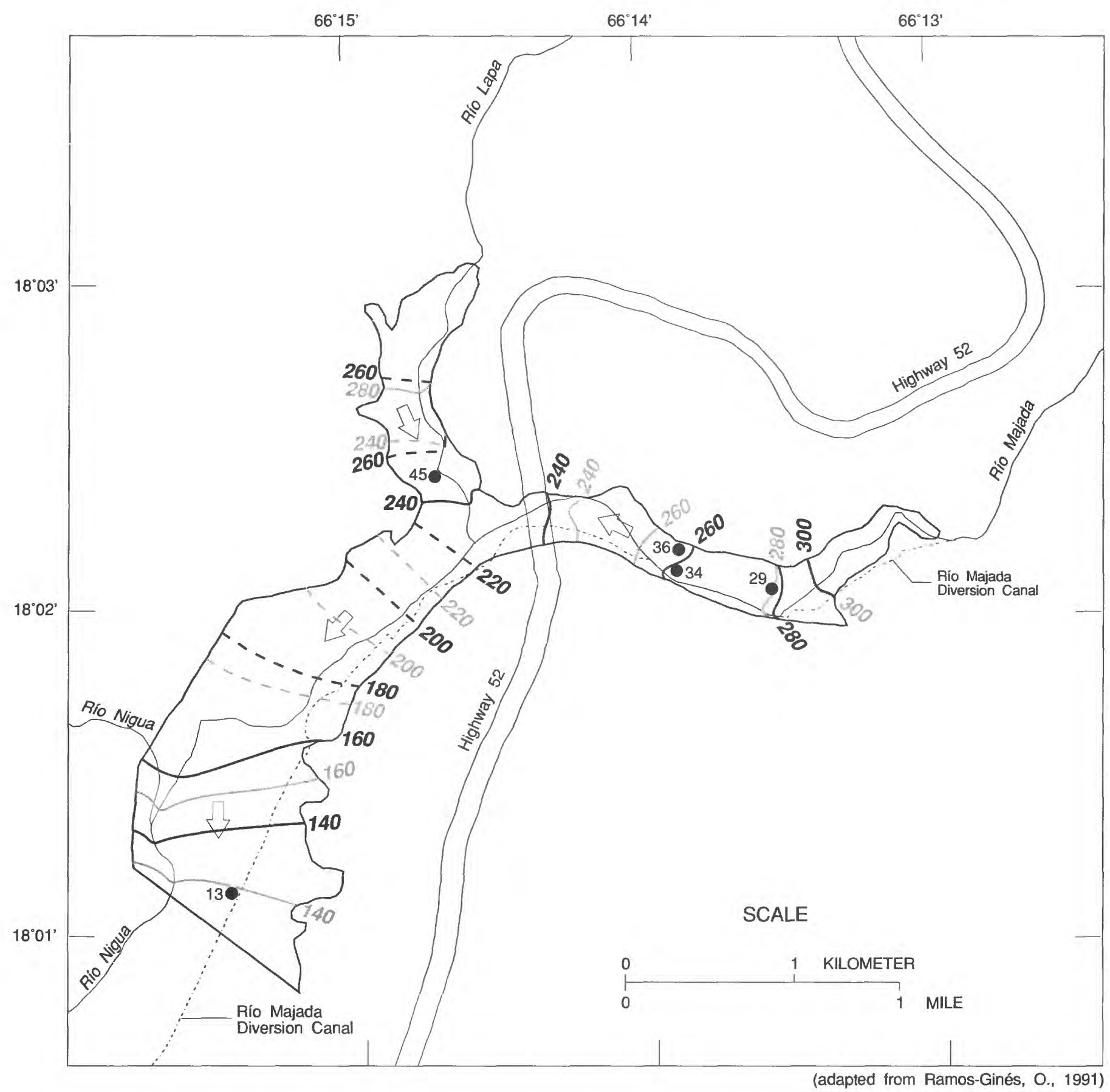

\section{EXPLANATION}

140 - - - - WATER-LEVEL CONTOUR, JULY 26, 1989. Dashed where aproximately located. Contour interval is 20 feet. Datum is mean sea level.

140 - . - - WATER-LEVEL CONTOUR, OCTOBER 18, 1989. Dashed where aproximately located. Contour interval is 20 feet. Datum is mean sea level.

$\checkmark$ GROUND-WATER FLOW DIRECTION

13 RECORDING WELL AND NUMBER

Figure 10. Ground-water levels during July 26 and October 18, 1989 in the study area. 
Table 4. Aquifer hydraulic-conductivity values as estimated from slug-injection and specific-capacity tests [---, no data is available]

\begin{tabular}{cccl}
\hline $\begin{array}{c}\text { Site } \\
\text { number } \\
\text { (figure 1) }\end{array}$ & $\begin{array}{l}\text { Hydraulic conductivity determined by: } \\
\text { Slug-injection } \\
\text { (feet per day) }\end{array}$ & $\begin{array}{l}\text { Specific-capacity } \\
\text { (feet per day) }\end{array}$ & \multicolumn{1}{c}{ Well screened in: } \\
\hline 13 & 94 & --- & Alluvium and highly weathered rocks \\
15 & 7 & --- & Highly weathered rocks. \\
18 & 96 & --- & Alluvium and highly weathered rocks. \\
20 & --- & 140 & Alluvium and highly weathered rocks. \\
22 & 14 & --- & Highly weathered rocks. \\
25 & 18 & --- & Alluvium and highly weathered rocks. \\
29 & 9 & --- & Highly weathered rocks. \\
36 & 13 & $-\cdots$ & Alluvium. \\
37 & 18 & 19 & Alluvium. \\
& & & \\
& & &
\end{tabular}

The total ground-water volume depleted by evapotranspiration, pumpage, and ground-water flow out of the study area was estimated to be $380 \mathrm{Mgal}$ (1,200 acre-ft) from January through August, 1989. The estimated value was computed by multiplying the average ground-water level decline in selected sub-areas by an assumed specific yield of 0.15 . This specific yield was used because the decline in ground-water levels occurred within the alluvial deposits.

The aquifer recovered to January 1989 water levels in response to higher streamflow seepage and rainfall infiltration during the wet season (September to October 1989). Each observation well showed a peak and then leveling of the water level during the wet season (fig. 11). This indicates an essentially full aquifer, probably as a result of high stream stage during that period. Because of the complete recovery of groundwater levels, there was no net loss or gain of water from aquifer storage during 1989.

Aquifer recharge during the year occurs from streamflow seepage, seepage from adjacent weathered rocks along the study area, and from rainfall infiltration. Streamflow seepage is the major source of aquifer recharge ( 81 percent), and was estimated by subtracting the streamflow at site 6 from the total streamflow entering the study area (sites 2 plus 3 minus 4 ) during 1989. Aquifer recharge by ground-water flow from adjacent rocks is probably no greater than 3 percent of the rainfall. The 3 percent of rainfall was obtained in a hydrologicbudget analysis for small drainage basins in Saint Thomas, U.S. Virgin Islands (Jordan and Cosner, 1973), and may be applied to southern Puerto Rico, which has a similar hydrogeologic setting. The rainfall within bedrock units having drainage (14 $\mathrm{mi}^{2}$ ) toward the study area was assumed equal to the measured rainfall of $16.5 \mathrm{in}$. in 1989. This ground-water flow component

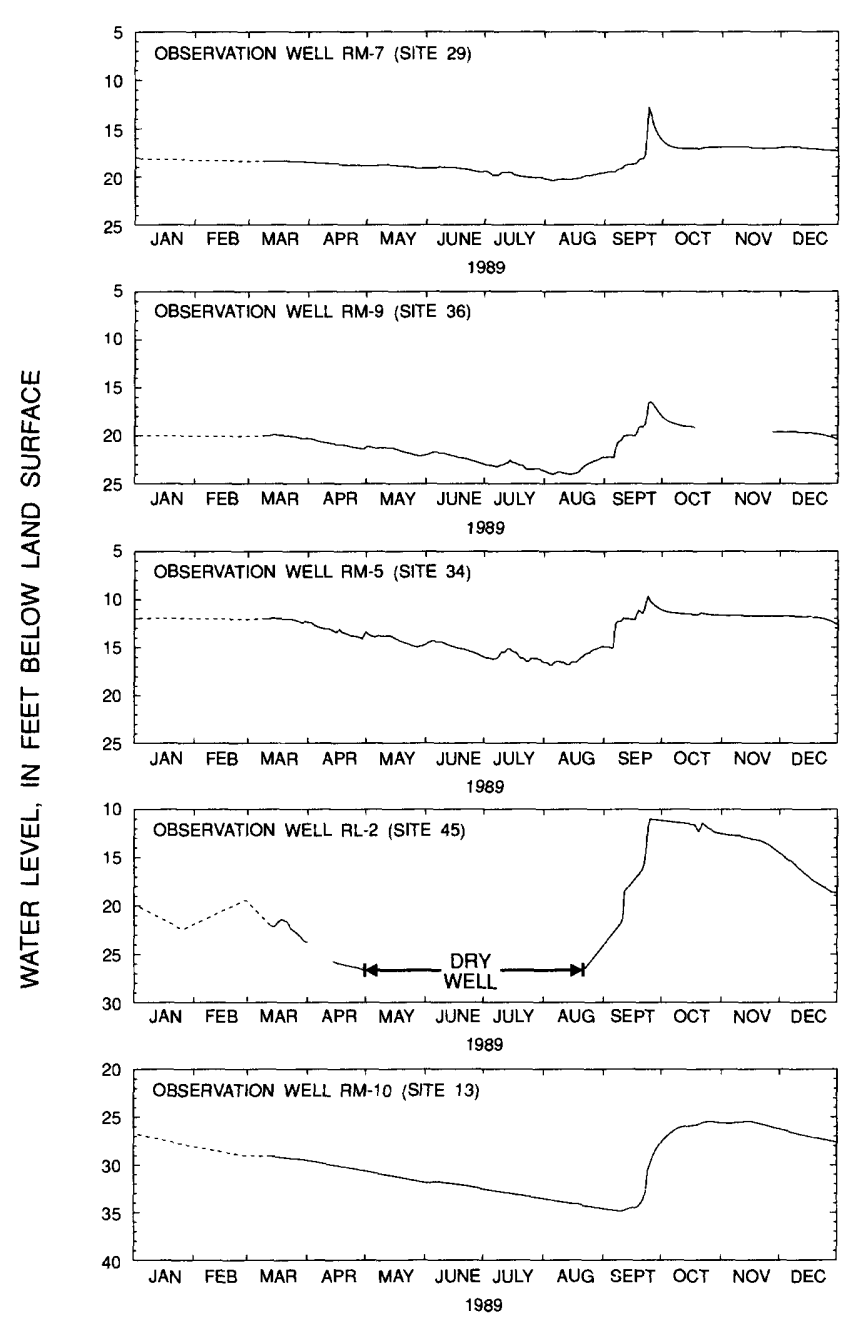

Figure 11. Ground-water level fluctuations at recording wells in the study area. 
contributes about 14 percent of the total aquifer recharge in the study area. Aquifer recharge by rainfall infiltration contributes about 5 percent of the total aquifer recharge and was estimated to be 10 percent of the total rainfall in the study area. This percentage of rainfall infiltration was estimated for other alluvial aquifers in southern Puerto Rico (Giusti, 1971 a, b), and is assumed to occur in the study area.

Monthly stream-discharge measurements indicated that the aquifer is recharged by streams most of the year. Stream reaches that gain water from the aquifer were not observed during the study, but probably occurred for a short time after the peak in water level that each recording well showed during the wet season (fig. 11). The estimated total aquifer recharge, by streams was about $190 \mathrm{Mgal}$ (580 acre-ft), and recharge from rainfall was about $19 \mathrm{Mgal}$ (60 acre-ft) during January to August 1989. Throughout 1989 , the aquifer recharge by streams was estimated to be $730 \mathrm{Mgal}(2,240$ acre-ft) and recharge from rainfall was estimated to be $44 \mathrm{Mgal}$ (140 acre-ft) during 1989. Aquifer recharge by seepage from weathered bedrock along the valley edges was estimated to be $120 \mathrm{Mgal}$ ( 380 acre-ft) in 1989.

Ground-water outflow at the southern-most part of the study area to the Salinas alluvial fan was estimated to be $300 \mathrm{Mgal} / \mathrm{yr}$ (930 acre-ft/yr) in 1989 and varied seasonally from 0.58 to 1.10 $\mathrm{Mgal} / \mathrm{d}$ (1.8 to $3.4 \mathrm{acre}-\mathrm{ft} / \mathrm{d}$ ) (fig. 12). The lowest outflow occurred during August, and the highest outflows occurred during October and November 1989. The outflow values were determined by multiplying the estimated average aquifer hydraulic conductivity near the southern-most boundary (110 $\mathrm{ft} / \mathrm{d})$ by the average width of the aquifer $(3,500 \mathrm{ft})$, the average hydraulic gradient $(50 \mathrm{ft} / \mathrm{mi})$, and the aquifer saturated thickness ( 19 to $39 \mathrm{ft}$ ) during the ground-water level surveys. The values were estimated with the assumption that the hydrologic conditions observed during the ground-water level and seepage surveys prevailed during the month in which they were conducted and that the system was at steady state (Darcy, 1856).

\section{Hydrologic Budget}

The hydrologic budget, which defines the balance between water gains and losses over a given period of time, is a useful tool for general management decisions, and is normally defined on a yearly basis. The water balance determined for the study area can be considered a generalized approximation of the overall water availability because the net change in aquifer storage is negligible. The hydrologic budget (table 5) was determined from monthly reconnaissances and from the estimated parameters discussed in the previous sections. The hydrologic budget is limited in use because of the uncertainty of some of the estimates: (1) the recharge from rainfall infiltration in the study area was assumed to be 10 percent of the total rain; (2) the ground-water flow from weathered rocks of surrounding areas into the alluviated area was assumed to be 3 percent of the rainfall that occurred within the areas that have drainage toward the study area; (3) the evapotranspiration loss was estimated to be the residual of the water balance, which may incorporate the possible errors of the other estimated values. The evapotranspiration in the Río Majada and Río Lapa alluvial aquifers is probably only occurring near the stream, where the water table is close to land surface; (4) the long-term yearly average was not represented by 1989 , which was an abnormally dry year; (5) steady-state conditions were assumed to prevail during the months when the ground-water level and seepage surveys were conducted; and (6) the hydrologic budget does not consider the possible amount of return flows from non-consumptive use of water (septic-tank effluents). Water-resources plans that use the water budget estimates given here should recognize these limitations.

The water budget that comprises both surface- and groundwater resources shows inflows and outflows estimated to be 7,530 acre-ft (table 5) within the study area for 1989.

Streamflow was the greatest inflow component of the overall hydrologic budget (surface- and ground-water resources) and accounted for 77 percent $(5,790$ acre-ft) of the total inflow to the alluvial valleys. Streamflow out of the study area $(3,900$ acre-ft/yr, 52 percent) and evapotranspiration (2,370 acre-ft/yr, 31 percent) were the two greatest outflow components of the overall water balance.

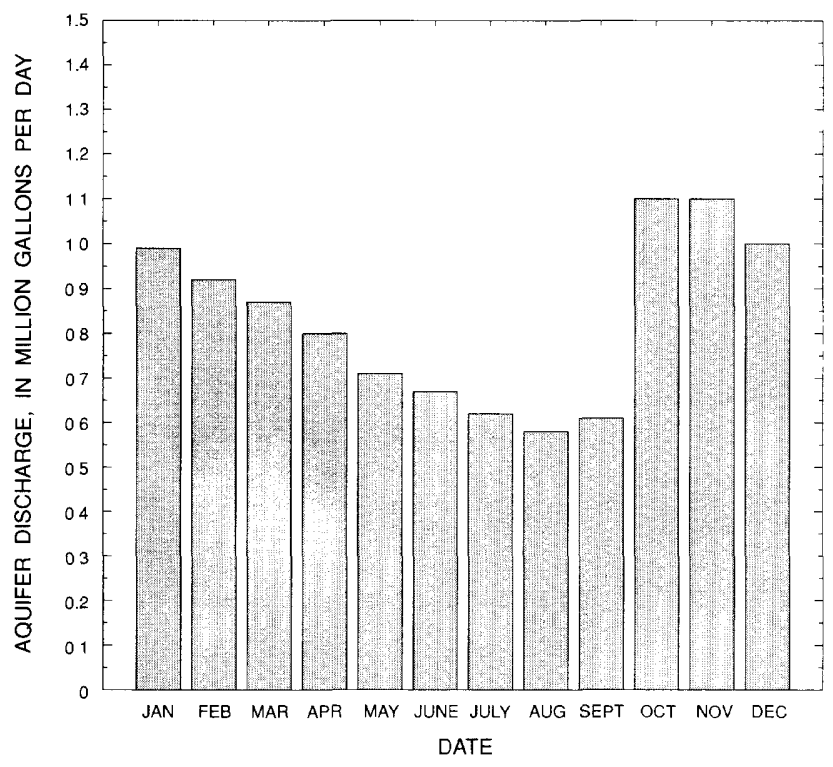

Figure 12. Estimated monthly aquifer discharge to the Salinas alluvial fan, 1989. 
The water budget of the ground-water system in the study area was estimated to be 2,760 acre-ft (table 5) for 1989.

Streamflow seepage $(2,240$ acre-ft/yr) was the greatest inflow component to the aquifer recharge and accounted for 81 percent of the total inflows to the valleys. Evapotranspiration from ground water (1,500 acre-ft) was the greatest outflow component and accounted for 54 percent of the ground-water system budget. Total ground-water withdrawals in the study area were about 330 acre-ft which is 12 percent of the estimated total water balance for the ground-water system for 1989 . Ground-water outflow from the study area to the Salinas alluvial fan aquifer was estimated to be 930 acre-ft for 1989 . Most of the surface-water runoff during 1989 at site 6 (fig. 1), which was estimated to be 3,600 acre-ft, probably contributed to the aquifer recharge of the Salinas alluvial fan.

\section{WATER QUALITY}

Ground-water and surface-water samples were collected on a monthly basis (except for September) during 1989 for analyses of common ions, fecal coliform and fecal streptococci bacteria, and VOC at two stream sites (site 1 and 2, fig. 1) and four production wells (sites 20, 3040 , and 45, fig.1). Waterquality analyses are listed in the appendix. The samples were collected to define the general quality and to define the effect of the dry season on the quality of the water resources. The potential effects of the water quality in the study area on the quality of the water resources in the Salinas alluvial fan is discussed.

The chemical quality of both surface-water and groundwater resources, in general, is adequate for major uses because primary standards for drinking water (U.S. Environmental Protection Agency, 1986) were not exceeded. The bacteriological quality of the surface water is poorer than that of the ground water. The quality of both surface and ground water was chemically and bacteriologically affected by seasonal variations in rainfall. Rainfall significantly alters streamflow and groundwater levels, and increases the concentrations of chemical constituents and fecal bacteria when both ground and surface water resources are depleted. Rock weathering, septic-tank

Table 5. Hydrologic budget of the Río Majada to the Río Lapa valleys for 1989

\begin{tabular}{|c|c|c|}
\hline Component & Value, in acre feet per year & Percentage \\
\hline \multicolumn{3}{|l|}{ OVERALL HYDROLOGIC BUDGET } \\
\hline $\begin{array}{l}\text { Inflows } \\
\text { Rainfall } \\
\text { Streamflow } \\
\text { Río Majada after diversion } \\
\text { Río Lapa } \\
\text { Ground-water seepage from bedrocks }\end{array}$ & $\begin{array}{r}7,530 \\
1,360 \\
5,790 \\
2,660 \\
3,130 \\
380\end{array}$ & $\begin{array}{r}100 \\
18 \\
77 \\
35 \\
42 \\
5\end{array}$ \\
\hline $\begin{array}{l}\text { Outflows } \\
\text { Evapotranspiration } \\
\text { Streamflow out of study area (site 6, fig.1) } \\
\text { Ground-water seepage at southern boundary } \\
\text { Pumpage } \\
\text { Upper Río Majada Valley } \\
\text { Lower Río Majada Valley } \\
\text { Río Lapa Valley }\end{array}$ & $\begin{array}{r}7,530 \\
2,370 \\
3,900 \\
930 \\
330 \\
200 \\
50 \\
80\end{array}$ & $\begin{array}{r}100 \\
31 \\
52 \\
12 \\
5 \\
3 \\
1 \\
1\end{array}$ \\
\hline \multicolumn{3}{|l|}{ GROUND-WATER SYSTEM BUDGET } \\
\hline $\begin{array}{l}\text { Inflows } \\
\text { Rainfall } \\
\text { Net streamflow seepage } \\
\text { Upper Río Majada Valley (after diversion) } \\
\text { Lower Río Majada Valley } \\
\text { Río Lapa Valley } \\
\text { Ground-water seepage from bedrocks }\end{array}$ & $\begin{array}{r}2,760 \\
140 \\
2,240 \\
480 \\
810 \\
950 \\
380\end{array}$ & $\begin{array}{r}100 \\
5 \\
81 \\
17 \\
30 \\
34 \\
14\end{array}$ \\
\hline $\begin{array}{l}\text { Outflows } \\
\text { Evapotranspiration } \\
\text { Ground-water seepage } \\
\text { Pumpage } \\
\text { Upper Río Majada Valley } \\
\text { Lower Río Majada Valley } \\
\text { Río Lapa Valley }\end{array}$ & $\begin{array}{r}2,760 \\
1,500 \\
930 \\
330 \\
200 \\
50 \\
80\end{array}$ & $\begin{array}{r}100 \\
54 \\
34 \\
12 \\
7 \\
2 \\
3\end{array}$ \\
\hline
\end{tabular}


effluents, animal wastes, and high evapotranspiration rates may be considered principle factors affecting the quality of both ground and surface water.

\section{Surface Water}

Analyses of surface-water samples collected at monthly intervals at gaging stations indicate that the water in the Río Majada and in the Río Lapa are predominantly a calciumbicabonate type (fig. 13). The water in the Río Majada was a calcium-sulfate type during April, July, and December 1989. The difference in chemical classification of surface water during part of the dry season may be the combination of the effects on water chemistry due to the presence of high fecal bacteria content, which may use other chemical species than dissolved oxygen for their metabolism, and to the residence time of ground water in the saprolite zone beyond the study area before reaching the stream channels. The Río Majada had less fecal bacteria and dissolved-solids concentrations but had a higher flow than the Río Lapa during the dry season.

Dissolved-solids concentrations of both streams ranged from 305 to $457 \mathrm{mg} / \mathrm{L}$ during 1989. Dissolved solids generally increased during the dry season from 305 to $401 \mathrm{mg} / \mathrm{L}$ in the Río Majada and from 348 to $457 \mathrm{mg} / \mathrm{L}$ in the Río Lapa (appendix). After the peak flows, which occurred in September and October, the dissolved-solids concentrations in the Río Majada increased to $418 \mathrm{mg} / \mathrm{L}$ in December 1989. The dissolved-solids concentration in the Río Lapa also remained high following the rains of September and October, and only decreased to $432 \mathrm{mg} / \mathrm{L}$ by December 1989. The surface water flowing to the Salinas alluvial fan during the wet season might have similar dissolved-solids concentrations.

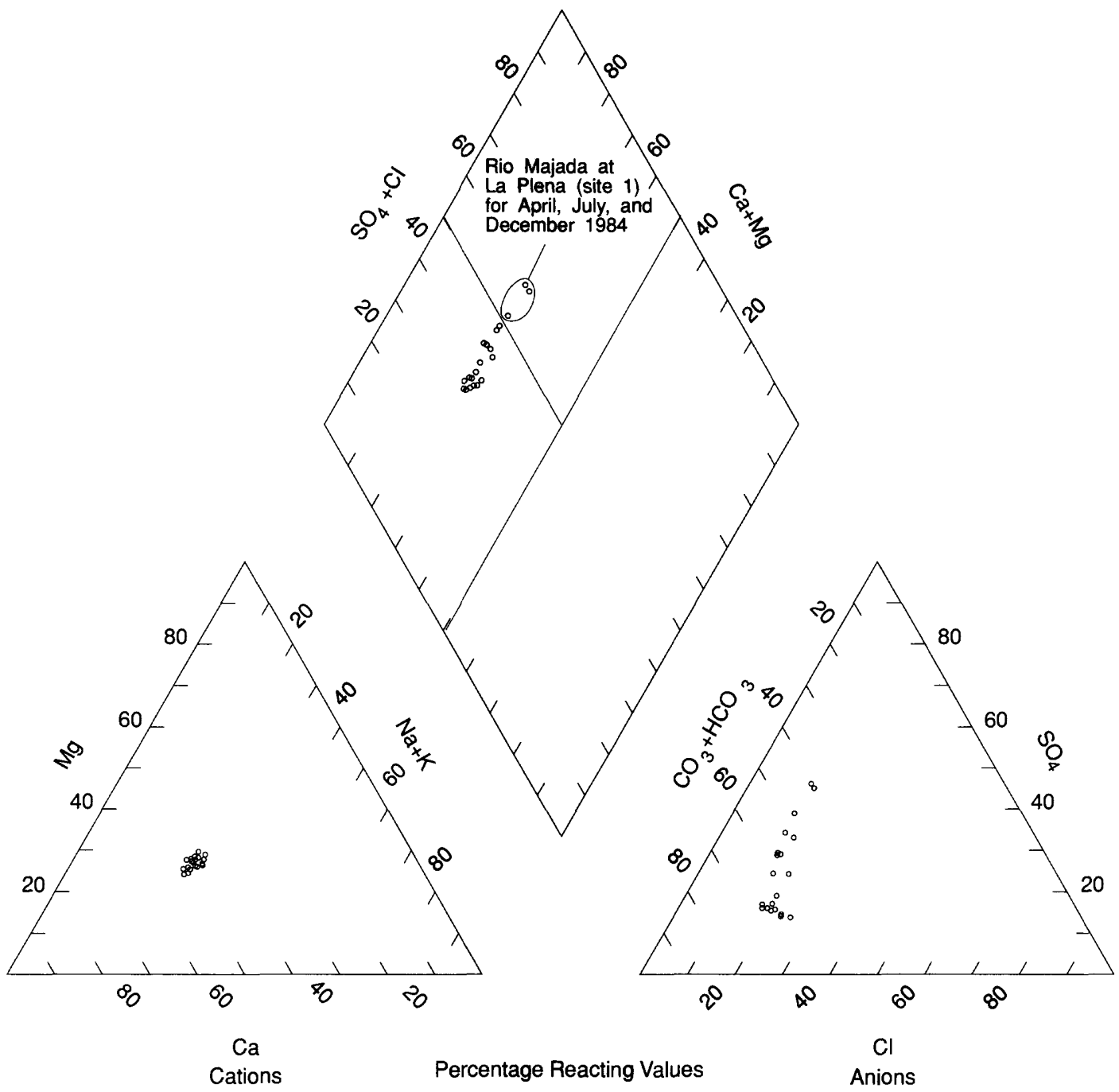

Figure 13. Chemical classification of surface water at stream gaging stations. 
Concentrations of dissolved sulfate, calcium, sodium, chloride, and magnesium showed noticeable changes during 1989 (fig. 14). The concentrations of these ions generally increased during 1989 in both streams. Nitrate plus nitrite (appendix) decreased during the dry season in the Río Lapa. Sulfate concentrations in the Río Majada and chloride and nitrate plus nitrite concentrations in the Río Lapa showed the largest changes in concentration during 1989. Sulfate concentrations in the Río Majada increased from 71 to $140 \mathrm{mg} / \mathrm{L}$ from January to July 1989 and decreased to $78 \mathrm{mg} / \mathrm{L}$ during the short wet season. In the Río Lapa, chloride concentrations increased from 47 to $71 \mathrm{mg} / \mathrm{L}$; however, nitrate plus nitrite concentrations decreased from $1.20 \mathrm{mg} / \mathrm{L}$ to below detection limit $(0.100$ $\mathrm{mg} / \mathrm{L}$ ) from January to July 1989 . This decrease in concentrations of nitrate plus nitrite may be the result of consumptive use of these ions by facultative bacteria, which are bacteria that grow in environments with or without oxygen, such as fecal bacteria.

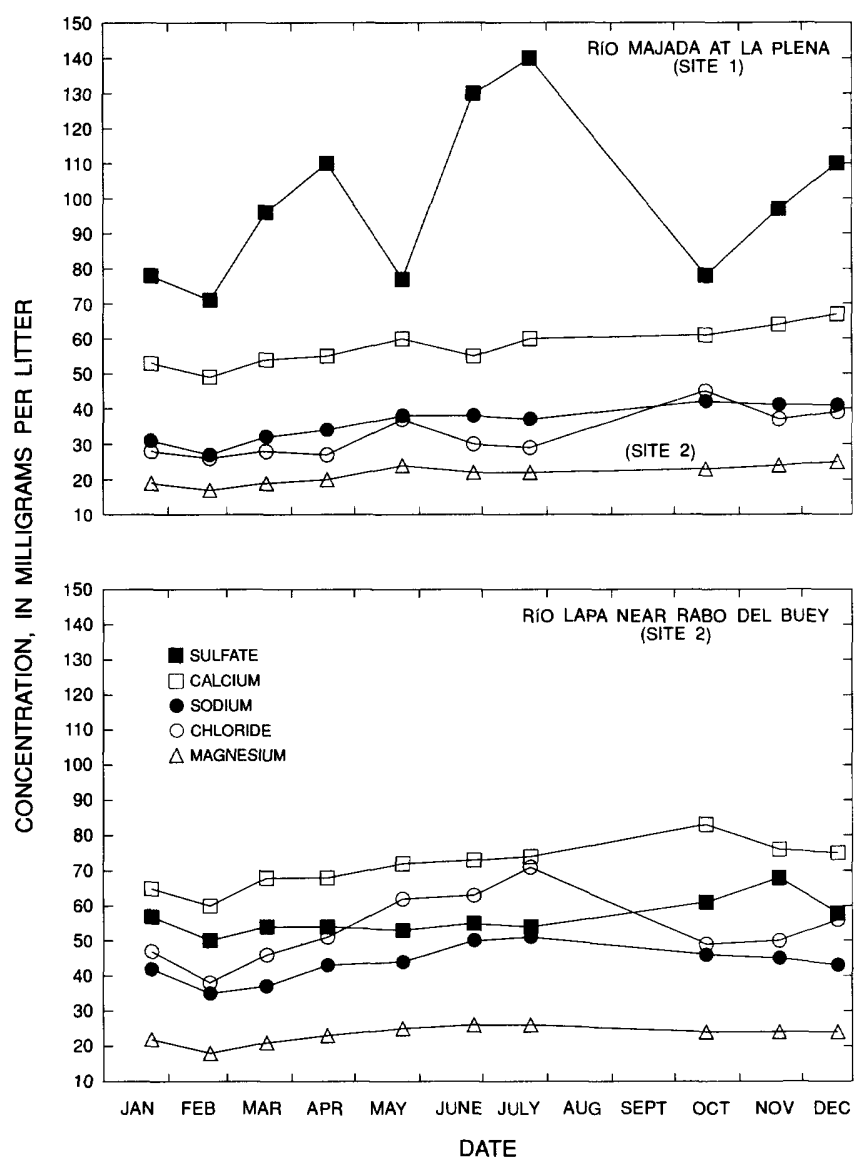

Figure 14. Dissolved concentrations of selected ions in streams during 1989.

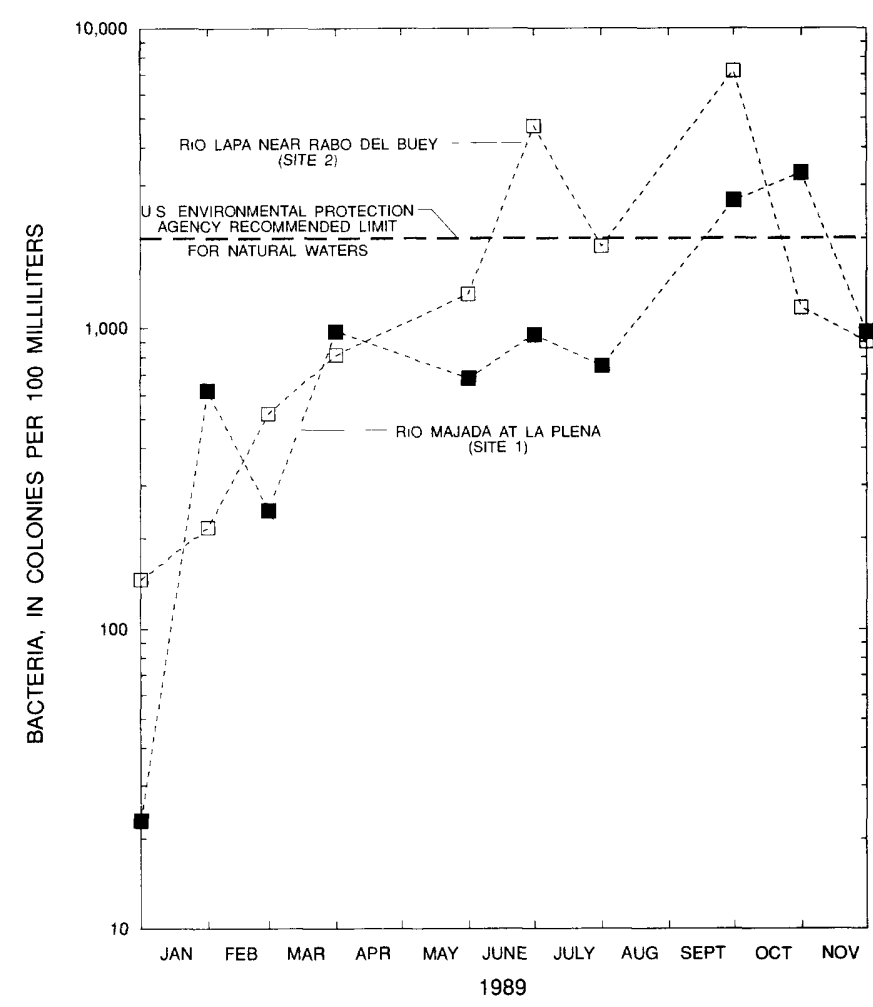

Figure 15. Fecal bacteria counts (fecal coliform plus fecal streptococcus) at Río Majada and Río Lapa stream gaging stations during 1989.

The only VOC detected in the surface-water samples was toluene. This chemical was detected twice in water samples from both streams, during January and April 1989, but was below the standards for drinking water of $5 \mu \mathrm{g} / \mathrm{L}$ (U.S. Environmental Protection Agency, 1986). The concentrations detected ranged from 0.40 to $1.4 \mu \mathrm{g} / \mathrm{L}$. Toluene is a common solvent and is also a constituent in gasoline, however; no point source or sources of toluene were found in the basins.

Fecal bacteria (fecal coliform plus fecal streptococcus) concentrations in the streams increased considerably through the dry season and remained relatively high during the short wet season. Bacteria counts increased from 23 to $950 \mathrm{col} / 100 \mathrm{ml}$ in the Río Majada and from 146 to $4,700 \mathrm{col} / 100 \mathrm{ml}$ in the Río Lapa from January to July 1989 (fig. 15). Bacteria counts during October 1989 were 2,670 and 7,200 col/100 ml for the Río Majada and the Río Lapa, respectively. This suggests that after the recharge events during the wet season, the infiltrated rainfall was flushing the ground water to the study area from the weathered zone of the volcanic rocks in the upper part of the basins. The fecal bacteria content of water samples collected from July to October 1989 in the Río Lapa and during October 
and November 1989 in the Río Majada exceeded the recommended limit for fecal bacteria content for natural waters of 2,000 col/100 ml (U.S. Environmental Protection Agency, 1986). Surface water that had high fecal bacteria concentration flowed to the Salinas alluvial fan area.

The ratio of fecal coliform to fecal streptococcus bacteria concentrations (FC/FS) in water from sites 1 and 2 suggest water contamination from human and animal sources (table 6). According to the American Public Health Association (1981), the ratio of fecal coliform to fecal streptococcus (FC/FS) is useful in determining the sources of these bacteria. Ratios less than 0.7 are usually indicative of animal sources, and ratios greater than 4.1 are usually indicative of human sources. Ratios between 0.7 and 4.1 may indicate a mixture of human and animal sources. Based on this approach, the bacterial contamination in the Río Majada during the dry season was predominantly indicative of a mixture from human and animal sources:
FC/FS ratios ranged from 2.0 to 2.8 (mixture of sources) during 4 months, from 0.35 to 0.42 (animal sources) during 2 months, and was a ratio of 15 (human sources) in February. Bacterial contamination in the Río Lapa during the same period was predominantly indicative of animal sources: FC/FS ratios ranged from 0.06 to 0.7 during 4 months (animal sources), from 0.53 to 3.0 during 2 months (mixture of sources), and was a ratio of more than 4.1 (human sources) in February.

\section{Ground Water}

Analyses of ground-water samples collected at monthly intervals during 1989 at four active wells (sites 20,30, 40, and 46; fig. 2) indicate that the water is predominantly a calciumbicarbonate type (fig. 16) with dissolved-solids concentrations that ranged from 352 to $516 \mathrm{mg} / \mathrm{L}$. The higher dissolved-solids concentrations $(366$ to $516 \mathrm{mg} / \mathrm{L}$ ) were collected from the Río

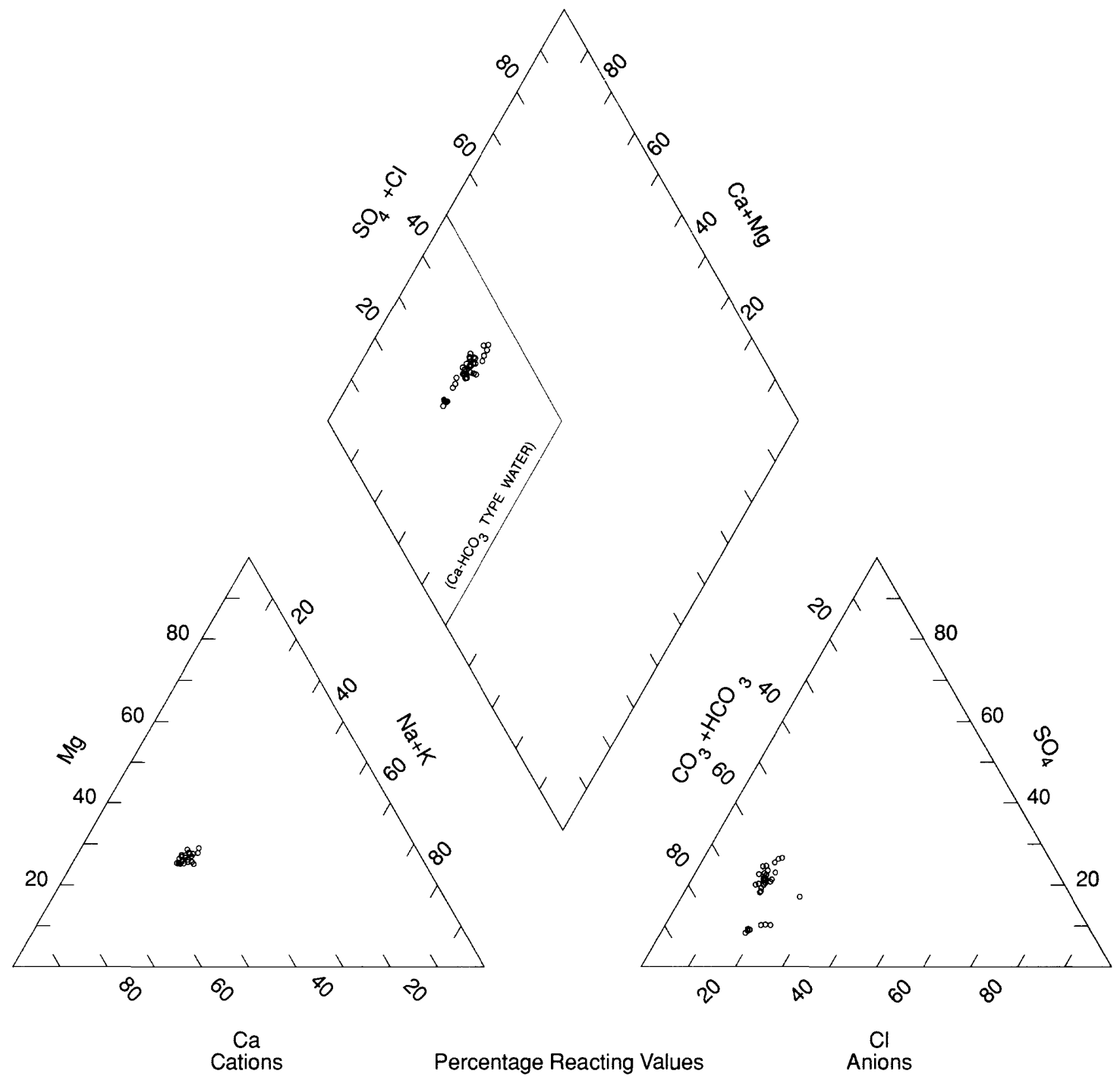

Figure 16. Chemical classification of ground water at selected sites. 
Table 6. Fecal coliform and fecal streptococcus bacteria concentrations during 1989

[---, value can not be expressed; <, indicates less than; col/100 ml, colony per 100 milliliters; YYMMDD, year/month/day]

\begin{tabular}{|c|c|c|c|c|c|c|}
\hline $\begin{array}{l}\text { Site } \\
\text { number } \\
(\text { fig. } 1 \& 2)\end{array}$ & $\begin{array}{l}\text { Site } \\
\text { name }\end{array}$ & $\begin{array}{l}\text { Sampling } \\
\text { date } \\
\text { (YYMMDD) }\end{array}$ & $\begin{array}{l}\text { Eecal } \\
\text { coliform (FC) } \\
(\text { col/100 ml) }\end{array}$ & $\begin{array}{l}\text { Fecal } \\
\text { streptococcus (FS) } \\
(\text { col } 1100 \mathrm{ml})\end{array}$ & $\begin{array}{l}\text { FC PLUS FS } \\
(\mathrm{COl} / 100 \mathrm{ml})\end{array}$ & $\begin{array}{l}\text { Ratio } \\
(\mathrm{FC} / \mathrm{FS})\end{array}$ \\
\hline
\end{tabular}

SURFACE WATER

1

Río Majada
at La Plena

890124
890221
890320
890418
890627
890724
890828
891016
891120
891218

Río Lapa near Rabo del Buey 890221 890320 890418 890626

890724

890828

891016

891120

891218
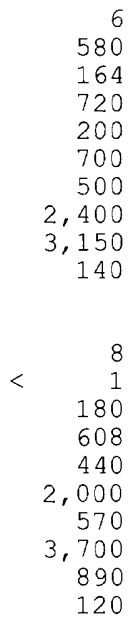

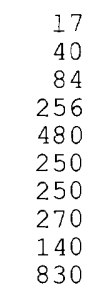

138

216

340

206
860

2,700

1,310

3,500

780

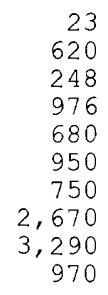

0.35

15

2.8

0.42

2.8

2.0

8.9

23

0.17

0.060

$-\overline{0.0}$

3.0

0.51

0.74

0.44

1.1

3.2

0.15

GROUND WATER

20

30

40

46

Naranjo c
Asphalt-1

Jesús

Albergue-3

(

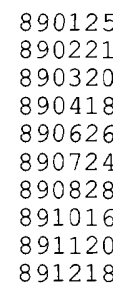

890125

890221

890320

890418

890627

890724

890124 890221

890320

890418

890626

890828

891016

891120

891218

890125

890221

890320

890414

890626

890724

890828

891016

891120

891218
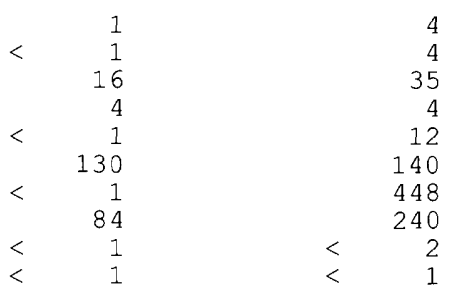

5
4
51
8
12
270
448
324
2

0.25

0.46

1.0

-... b

0.93

0.35

-... b

----

0.21

1.3

0.70

0.54

0.71

0.80

-.--

… b

- -

---

1. 0

8.7

$-\cdots$

$---\frac{5}{2}$

$<$

$<\quad 1$

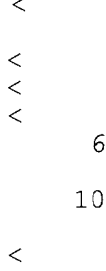

$---$

0.83

-.--

$-\cdots$

1.5

0.010

27

1.0

Note: a Ratio less than 0.7 is indicative of animal source; greater than 4.1 is indicative of human source; and between 0.7 and 4.1 is indicative of mixture of animal and human sources (American Public Health Association, 1981).

b Ratio is considered to be more than 4.1 , fecal-bacteria population is predominantly streptococcus

c Chlorinated water sample. 
Lapa Valley (site 46; appendix). Concentrations of dissolved sulfate, calcium, sodium, chloride, and magnesium showed noticeable changes at all ground-water sites during 1989 (fig. 17). Concentrations of these ions generally increased at site 40 in the upper part of the Río Majada Valley and at site 20 in the lower part of the Río Majada Valley, but showed little change at site 46 in the head of alluvium in the Río Lapa Valley and at site 29 in the upper part of the Río Majada Valley (appendix).

Nitrate plus nitrite concentration (appendix) increased during the dry season at sites 20 and 30 (fig. 1), but decreased at well site 40 and 46 . The concentration of nitrate plus nitrite increased after the wet season at sites 40 and 46 but decreased at site 20 .

In addition to detection at the surface-water sites 1 and 2, toluene was detected in the ground-water sampling sites during January to April 1989, and the concentrations ranged from 0.20 to $0.50 \mu \mathrm{g} / \mathrm{L}$. Other VOC's detected in the ground water were dichlorobromomethane, 1,2-dichloroethane, chlorodibromomethane, and chloroform (appendix); however, these compounds could be a result of the chlorination of the groundwater pumped at well sites 40 and 46 . The formation of these VOC's in the ground-water chlorination process is related to the presence of humic substances (Wood and others, 1981).

Detected concentrations in the water samples ranged from 0.20 (sites 40 and 46 ) to $4.5 \mu \mathrm{g} / \mathrm{L}$ (site 46). Bromoform was also detected in water samples collected at both sites and ranged from 0.20 (sites 40 and 46 ) to $4.1 \mu \mathrm{g} / \mathrm{L}$ (site 40 ).

Low aquifer recharge by rainfall infiltration and streamflow seepage, and high evapotranspiration rates from ground water during the dry season resulted in an increase in dissolved-solids concentrations at site 46 , which exceeded the secondary drinking water standard of $500 \mathrm{mg} / \mathrm{L}$ (U.S. Environmental Protection Agency, 1986) during four relatively dry months in
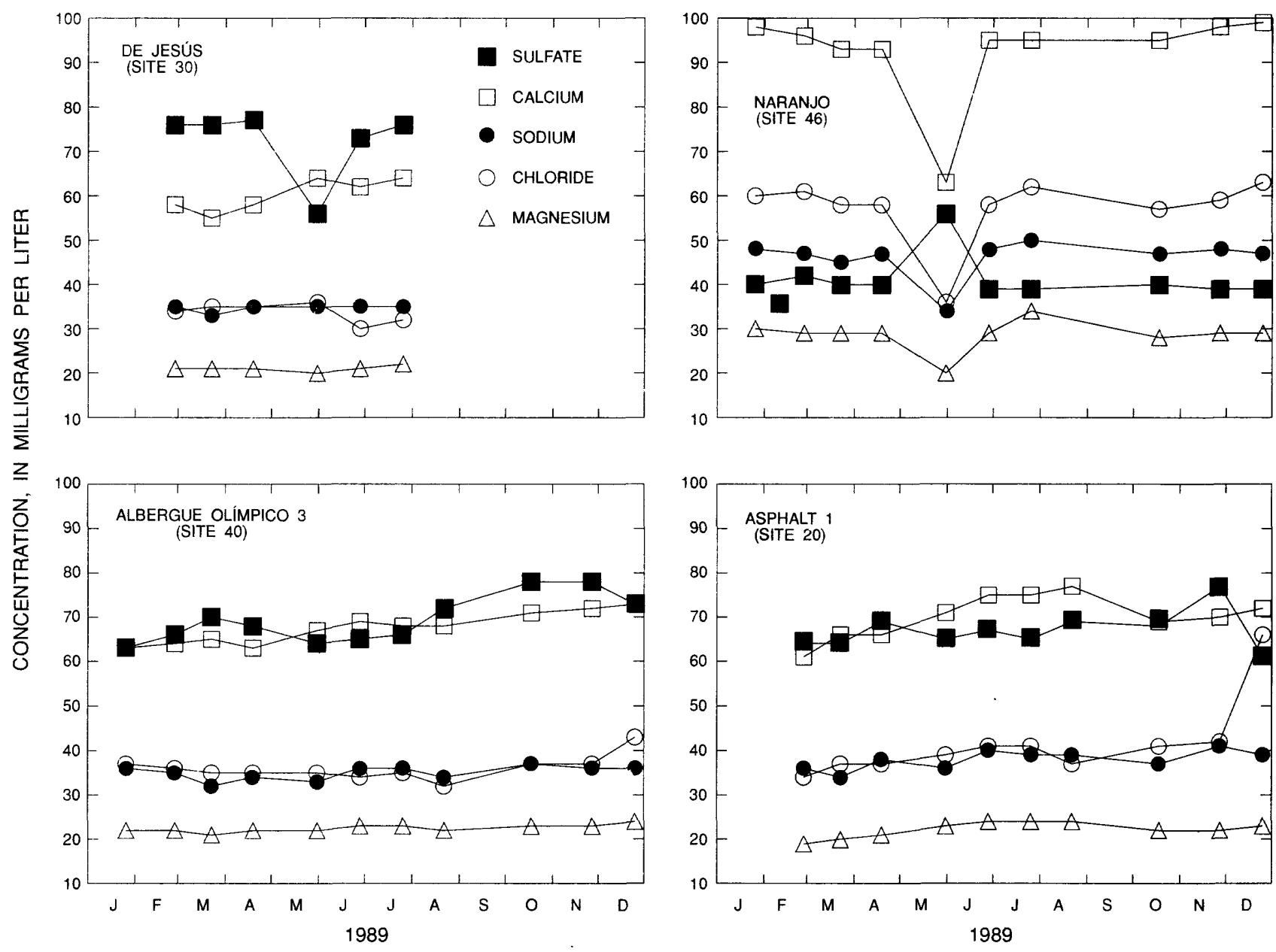

Figure 17. Dissolved concentrations of selected ions in the ground water at selected sites during 1989. 
1989. The water samples of January, July, November, and December 1989 at site 46 contained dissolved-solids concentrations that ranged from 507 to $516 \mathrm{mg} / \mathrm{L}$. Dissolved-solids concentrations in the other sampled wells did not exceed the secondary drinking water standard.

The ground-water flow to the Salinas alluvial fan probably had dissolved solids concentration as high as $421 \mathrm{mg} / \mathrm{L}$. This maximum concentration of dissolved solids was obtained from water samples collected at site 20 which is near the head of the Salinas alluvial fan. The dissolved-solids concentrations at site 20 ranged from 362 to $421 \mathrm{mg} / \mathrm{L}$ during 1989, and during the dry season increased from $362 \mathrm{mg} / \mathrm{L}$ in January to $420 \mathrm{mg} / \mathrm{L}$ in August.

The fecal bacteria (fecal coliform plus fecal streptococcus) counts in ground water varied from site to site, and increased during the dry season at each site. Although ground water at every sampled site contained fecal bacteria during 1989, the greatest concentrations were observed near the southwestern boundary of the study area. Well site 20 (fig. 2) showed an increase in the fecal bacteria from about $5 \mathrm{col} / 100 \mathrm{ml}$ in January to $448 \mathrm{col} / 100 \mathrm{ml}$ in August 1989 (table 6), which indicate that the ground-water flow to the Salinas alluvial fan probably had high concentrations of fecal bacteria during the dry season. The fecal bacteria concentration at well site 30 had increased by July 1989 to $704 \mathrm{col} / 100 \mathrm{ml}$, which was the highest count for ground water during the investigation.

Fecal bacterial concentration in well site 46 increased from less than $1 \mathrm{col} / 100 \mathrm{ml}$ in January to $186 \mathrm{col} / 100 \mathrm{ml}$ in August 1989 , and a corresponding increase in bacteria counts from 146 to $1,890 \mathrm{col} / 100 \mathrm{ml}$ was observed in the Río Lapa during this period. This suggests that the high concentrations of fecal bacteria in the Río Lapa, which completely seeps into the aquifer most of the year, and in the ground water flowing from adjacent weathered rocks to the study area increased the amount of fecal bacteria in the aquifer within the study area. During the dry season, when the concentration of fecal bacteria increases, the amount of chlorine used to disinfect pumped water may not be effective. Studies have shown that raw water treated only with chlorination methods should have concentrations of bacteria less than or equal to $50 \mathrm{col} / 100 \mathrm{ml}$ to consistently meet the drinking water standard of $1 \mathrm{col} / 100 \mathrm{ml}$ (Berger and Argaman, 1983).

The existence of 11 leaching fields of septic tanks near well sites $38,39,40$, and 41 pose a potential water-quality problem to these wells. However, no fecal bacteria in the water samples could be related to the leaching fields. When water samples collected from the well at site 40 contained fecal bacteria, the upstream well (site 30 ) also contained fecal bacteria.
Ground-water samples had fecal bacterial ratios (FC/FS) that suggested water contamination from both animal and human sources (table 6). The potential sources of contamination are contaminated surface water recharging the alluvial aquifer, effluent from septic tanks, and animal wastes from farms. During January to April 1989, the FC/FS ratios were predominantly indicative of contamination from animal wastes, but no significant difference in sources were found during the last 4 months (May to August) of the dry season. The FC/FS in two wells (40 and 46) was indicative of human sources only during October 1989 (wet season), indicating ground-water contamination from septic-tank effluents.

\section{POTENTIAL ALTERNATIVES FOR WATER- RESOURCES DEVELOPMENT}

The potential alternatives for water-resources development may be inferred from aspects of the hydrologic system such as aquifer recharge and ground- and surface-water outflow of the study area. Water-supply demands at the Albergue Olímpico are expected to increase (fig. 18) by an additional $36 \mathrm{Mgal} / \mathrm{yr}$ (110 acre-ft/yr) by 1995 (J. Cruz-Vález, Albergue Olímpico, oral commun., 1990). This additional amount of water can be provided from existing well fields. The only limitation to present and future ground-water development would be the occurrence of a major drought, or the necessity to continue releasing surface-water flow, or to continue allowing the ground-water flow to the Salinas alluvial fan.

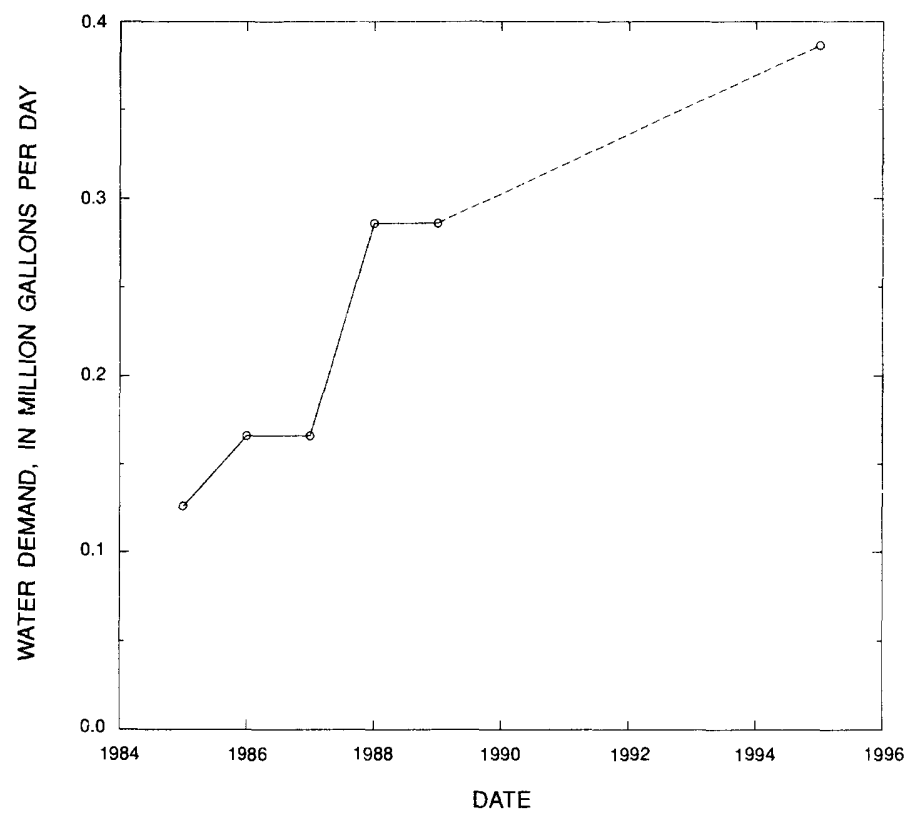

Figure 18. Projection of water demand to the year 1995 in the Río Majada and Río Lapa alluvial valleys. 
Because rainfall is the principal factor affecting streamflow in the study area, historical rainfall trends can be used to assess the variations in rainfall for future years. During a drought, the decrease in streamflow will lower ground-water levels and reduce the availability of ground water.

The 10-year moving average of rainfall, computed from long-term data (1908 to 1989) obtained from NOAA records (fig. 19) suggest the occurrence of relatively low rainfall periods once every 30 years at Jájome Alto raingage (site 9) in the Río Majada headwaters, located 5 mi northeast of the study area, and at Aguirre (site 11), located in Salinas, $5 \mathrm{mi}$ south of the study area (Gómez-Gómez and Heisel, 1980). The 10-year moving average shows that at least $10 \mathrm{in}$. of difference exists between the average rainfall of dry and that of wet years in the coastal plain. In the Río Majada headwaters, the difference between the average rainfall of dry and wet years may be as much as $25 \mathrm{in}$. Comparison of the moving averages indicates that events such as wet and dry years in areas relatively close together are not totally comparable.

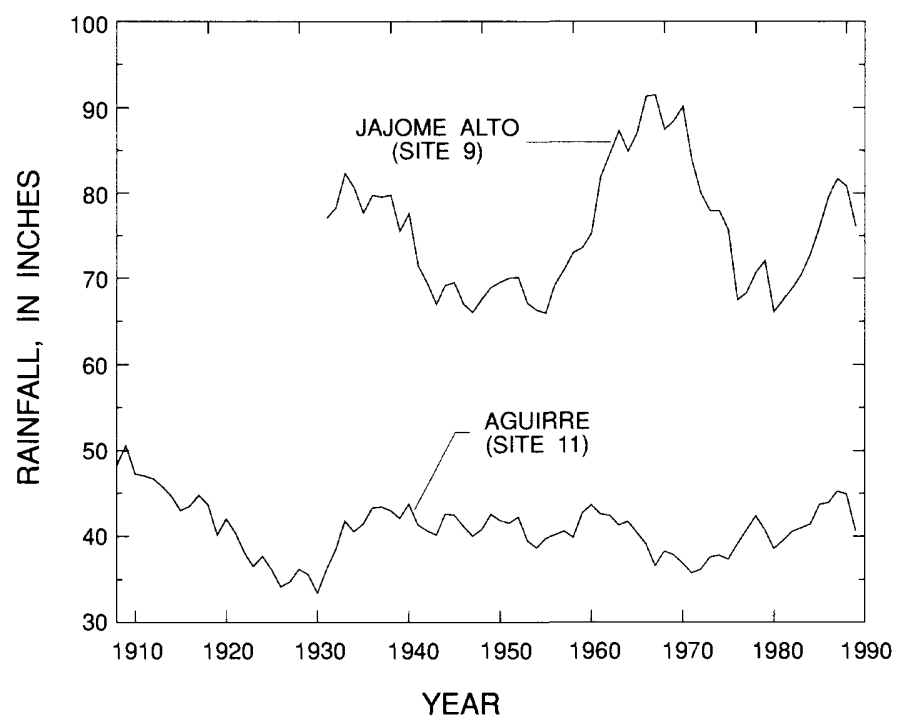

Figure 19. Ten-year moving average rainfall pattern at selected rainfall stations in Puerto Rico (modified from Gómez-Gómez and Heisel, 1980).

\section{Surface Water}

The only additional source of surface water is that from surface runoff during the wet season (3,900 acre- $\mathrm{ft} / \mathrm{yr}$, table 5). This additional water could be stored in small reservoirs and, after treatment, used to supply the expected water demand in the study area. Alternatively, the additional water could be used to gradually recharge the aquifer during the dry season. This additional recharge to the aquifer would offset the effects of increased pumpage on water levels or may be used to supplement the ground-water flow to the Salinas alluvial fan.

\section{Ground Water}

Existing ground-water resources can also be developed to meet additional water demands by intercepting most of the ground-water flow to the Salinas alluvial fan. Under present conditions, the amount of ground-water flow out of the study area ( 930 acre-ft/yr, table 5) could be reduced by the construction of low-capacity wells in selected areas. The most adequate area is probably the lower Río Majada Valley where the ground-water flow from the upper part of the Río Majada Valley and from the Río Lapa Valley could be intercepted. Interception of ground-water flow would reduce the inflow to the Salinas alluvial fan and result in lower ground-water levels in that area.

Higher streamflows than those observed during 1989 could provide greater recharge to the aquifer. Under average longterm conditions, the streams may have higher flows than those found in 1989 , because higher rainfall normally occurs in the headwater areas.

Under drought conditions, the use of low-capacity wells in the lower part of the Río Majada Valley to reverse the hydraulic gradient may reduce the amount of ground-water leaving the study area, and the water withdrawn can be used to artificially recharge the aquifer in upgradient areas. The natural hydraulic gradient of the aquifer allows ground-water to flow from the upstream areas to the downstream areas. Existing wells that pump from the aquifer may reduce ground-water flow from the study area to the Salinas alluvial fan, although a significant amount of water may still flow out of the pumping area.

\section{SUMMARY AND CONCLUSIONS}

Low rainfall during extended dry periods, common in southern Puerto Rico, results in reduced water availability during those periods. Streamflow decreases by at least 80 percent during the dry season from January to August, and ground-water levels may decline by about $10 \mathrm{ft}$ because of the 
decrease in aquifer recharge. In addition to the generally limited water supply, rapidly expanding poultry farms and suburban development may represent potential water-quality problems. Concentrations of inorganic and organic constituents and fecal bacteria (fecal coliforms and fecal streptococcus) may increase as surface- and ground-water resources are depleted.

Rainfall in the headwaters upstream of the study area was 35 percent less in 1989 than the 1951-80 annual average of 77.2 inches, and about 3 times greater than rainfall in the study area during 1989. In the study area, daily rainfall exceeded daily pan evaporation rates on only 25 of the 335 days monitored.

The Río Lapa had the greatest flow (3,130 acre-ft) at the gaging stations, and the flow was about 1.05 times the flow of the Río Majada (2,990 acre-ft) in 1989. Most of the flow from the Río Majada and the Río Lapa occurred during the wet season and flowed out of the study area to the Salinas alluvial fan (3,900 acre-ft). During the predominantly low-flow periods of January to August 1989, flow in the Río Majada (816 acre-ft) was about 3 times the flow in the Río Lapa ( 287 acre-ft) at the gaging stations. However, about 40 percent of the flow of the Río Majada was diverted (330 acre-ft) before reaching the study area. The diversion reduces the streamflow reaching the alluvial area and recharging the aquifer.

Streamflow seepage surveys indicated rates of streamflow loss to the ground-water system as high as $0.60,1.28$, and 2.55 $\mathrm{ft}^{3} / \mathrm{s}$ per mi for the upper and lower alluvial reaches of the Río Majada, and for the alluvial reach of the Río Lapa, respectively. At their confluence, both the Río Majada and the Río Lapa are dry most of the year, and streamflow out of the study area in 1989 occurred only during the high flows of September and October. The 60-day low-flow for the Río Majada and the Río Lapa at the gaging stations may be as low as 0.2 and $0.04 \mathrm{ft}^{3} / \mathrm{s}$ every 10 years, respectively, as estimated from low-flow frequency analysis.

Ground water in the study area is under water-table conditions in two distinct, but hydraulically connected, hydrogeologic units: alluvial deposits and highly-weathered volcanic rocks. Aquifer hydraulic-conductivity values range from 7 to $140 \mathrm{ft} / \mathrm{d}$ and generally increase toward the southwestern studyarea boundary. The apparent range of hydraulic conductivity for the highly weathered part of the volcanic rocks is 7 to $14 \mathrm{ft} / \mathrm{d}$.

Average depths to water range from about $12 \mathrm{ft}$ at upper valley areas to about $30 \mathrm{ft}$ below land surface in the southernmost part of the study area. The water table declined about $4 \mathrm{ft}$ in the upper part of the Río Majada Valley, $12 \mathrm{ft}$ in the Río Lapa Valley, and $9 \mathrm{ft}$ in the lower Río Majada Valley from January to August 1989. Water levels in observation wells declined by $0.03 \mathrm{ft} / \mathrm{d}$ for the same period at wells in the upper and lower parts of the Río Majada Valley. Water levels in the Río Lapa Valley declined by $0.05 \mathrm{ft} / \mathrm{d}$ for the same period.

Recharge to the ground-water system occurs from three sources: streamflow seepage from the Río Majada and the Río Lapa, seepage from adjacent weathered bedrocks along the valley edges, and from rainfall infiltration in the study area. Streamflow seepage is the major source of aquifer recharge (81 percent; 2,240 acre-ft/yr). Seepage from adjacent weathered bedrocks contributed about 14 percent ( 380 acre-ft/yr), and rainfall infiltration contributed only about 5 percent $(140$ acre- $\mathrm{ft} / \mathrm{yr})$ of the total aquifer recharge in the study area $(2,760$ acre-ft/yr).

Losses from the ground-water system are from pumpage, ground-water outflow at the southernmost part of the study area, and evapotranspiration. The total combined loss was estimated to be 2,760 acre-ft during 1989.

The quality of the water resources is affected by seasonal variations in rainfall, which significantly alter streamflow and ground-water levels. Rock weathering, septic-tank effluents, animal wastes, and high evapotranspiration rates may be the principal factors affecting the quality of both surface and ground water.

Dissolved-solids concentrations increased during the dry season from 305 to $457 \mathrm{mg} / \mathrm{L}$ in the surface water and from 352 to $516 \mathrm{mg} / \mathrm{L}$ in the ground water. Water samples from well site 46 had dissolved-solids concentrations that exceeded the secondary drinking water standard of $500 \mathrm{mg} / \mathrm{L}$ during four relatively dry months. The water samples of January, July, November, and December 1989 at this well site contained dissolved-solids concentrations that ranged from 507 to 516 $\mathrm{mg} / \mathrm{L}$.

Volatile organic compounds (VOC) were detected in surface and ground water. Toluene was the only VOC detected in the surface water, and concentrations detected ranged from 0.20 to $1.4 \mu \mathrm{g} / \mathrm{L}$, which did not exceeded the standard for drinking water of $5 \mu \mathrm{g} / \mathrm{L}$. Toluene was also detected in the ground water and the concentrations ranged from 0.20 to 0.50 $\mu \mathrm{g} / \mathrm{L}$. Other VOC's detected in ground water were dichlorobromomethane, 1,2-dichloroethane, chlorodibromomethane, and chloroform. These compounds could be by-products of chlorination of the ground water pumped at well sites 46 and 40 .

Fecal bacteria (fecal coliforms plus fecal streptococcus) concentrations in the streams increased through the dry season and remained relatively high during the short wet season. Fecal bacteria counts increased from 23 to $950 \mathrm{col} / 100 \mathrm{ml}$ in the Río Majada and from 146 to $4,700 \mathrm{col} / 100 \mathrm{ml}$ in the Río Lapa during January to July 1989 . Fecal bacteria counts during October 1989 were 2,670 and 7,200 col/100 ml for the Río 
Majada and the Río Lapa, respectively. The fecal bacteria content of water samples collected from July to October 1989 in the Río Lapa and during October and November 1989 in the Río Majada exceeded the recommended fecal bacteria content for natural waters of $2,000 \mathrm{col} / 100 \mathrm{ml}$.

Although every sampled ground-water site contained fecal bacteria during 1989 , the greatest concentrations were observed near the southwestern boundary of the study area. The fecal bacteria concentration at each ground-water site increased during the dry period. Water samples from a well near this area (well site 20) showed an increase in the fecal bacteria from about $5 \mathrm{col} / 100 \mathrm{ml}$ in January to $448 \mathrm{col} / 100 \mathrm{ml}$ in August 1989. This indicates that the ground water flowing to the Salinas alluvial fan during the dry season of 1989 had high fecal bacteria content. The quality of water at well site 46 appears to be affected by the water quality of the adjacent Río Lapa. The fecal bacteria concentrations in well site 46 increased from less than $1 \mathrm{col} / 100 \mathrm{ml}$ in January to $186 \mathrm{col} / 100 \mathrm{ml}$ in August 1989, and a corresponding increase in bacteria counts from 146 to
$1,890 \mathrm{col} / 100 \mathrm{ml}$ was observed in the Río Lapa during this same period.

The water resources in the Río Majada and Río Lapa basins could be developed to supply the expected demand of 110 acre-ft by 1995 . The only limitation to the development would be the occurrence of a major drought, or a need to continue releasing surface-water flow, or continue allowing flow of ground water to the Salinas alluvial fan. Surface-water runoff from the study area (3,900 acre-ft/yr) could be stored in small reservoirs and after treatment, used to supply the expected water demand. Alternatively, the additional water could be used to recharge the aquifer during the dry season. Ground-water flow out of the study area ( $930 \mathrm{acre}-\mathrm{ft} / \mathrm{yr}$ ) to the Salinas alluvial fan could be reduced by increasing ground-water withdrawals from the downstream part of the Río Majada Valley where ground-water flows coming from the upper Río Majada and Río Lapa valleys could be intercepted. 


\section{REFERENCES}

American Public Health Association, 1981, Standard methods for the examination of water and wastewater (15th ed.): Washington, D.C., $819 \mathrm{p}$.

Berger, P.S., and Argaman, Y.L., 1983, Assessment of microbiology and turbidity standards of water: U.S. Environmental Protection Agency 570/9-83-001.

Berryhill, H.L., and Glover, Lynn, 1960, Geology of the Cayey Quadrangle, Puerto Rico: U.S. Geological Survey Miscellaneous Geologic Investigations Map I-319, 1 pl.

Bouwer, Herman, and Rice, R.C., 1976, A slug test for determining hydraulic conductivity of unconfined aquifers with completely or partially penetrating wells: Water Resources Research, v. 12, no. 3, p. 423-428.

Britton, L.J., and Greeson, P.E., 1977, Methods for collection and analysis of aquatic biological and microbiological samples: Techniques of Water-Resources Investigations of the U.S. Geological Survey, Book 5, Chapter A4, 363 p.

Darcy, Henry, 1856, Les fontaines publiques de la ville de Dijon: Paris, Victor Dalmont, 647 p.

Díaz, J.R., 1974a, Coastal salinity reconnaissance and monitoring system, south coast of Puerto Rico: U.S. Geological Survey Open-File Report 74-1, 28 p.

1974b, Ground-water levels in the south coast of Puerto Rico, February 1974: U.S. Geological Survey Open-File Report, Puerto Rico Data Release No.1, 24 p.

Ezekiel, Michael, and Fox, K.A., 1959, Methods of correlation and regression analysis: New York, John Wiley \& Sons, Inc., $548 \mathrm{p}$.

Giusti, E.V., 1968, Water resources of the Juana Díaz area, Puerto Rico: U.S. Geological Survey Water-Resources Bulletin 8, 43 p.

1971a, Regional specific yield of Coamo fan, Puerto Rico, computed by water budget method, in Geological Survey Research 1971, Chapter B: U.S. Geological Survey Professional Paper 750-B, p. B248-B251.

1971b, Water resources of the Coamo area, Puerto Rico: U.S. Geological Survey Water-Resources Bulletin 9, $31 \mathrm{p}$.

Glover, Lynn, 1961, Preliminary report on the geology of the Coamo quadrangle, Puerto Rico: U.S. Geological Survey Miscellaneous Geologic Investigation Map I-335, 1 pl.

1971, Geology of the Coamo area, Puerto Rico and its relation to the volcanic arc-trench association: U.S. Geological Survey Professional Paper 636, 102 p.

Gómez-Gómez, Fernando, and Heisel, J.E., 1980, Summary appraisal of the nation's ground-water resources Caribbean region: U.S. Geological Survey Professional Paper 813-U, $32 \mathrm{p}$.

Haire, W.J., 1971, Floods in the Salinas area, Puerto Rico: U.S. Geological Survey Hydrologic-Investigation Atlas HA-447.
, 1972, Floods of October 5-10, 1970 in Puerto Rico: U.S. Geological Survey Water-Resources Bulletin 12, 42 p.

Jordan, D.G., and Cosner, O.J., 1973, A survey of the water resources of Saint Thomas, U.S. Virgin Islands: U.S. Geological Survey Open-File Report, 55 p.

McClymonds, N.E., and Díaz, J.R., 1972, Water resources of the Jobos area, Puerto Rico: U.S. Geological Survey WaterResources Bulletin 13, 32 p.

Morris, D.A., and Johnson, A.I., 1967, Summary of hydrologic and physical properties of rocks and soil materials as analyzed by the hydrologic laboratory of the U.S. Geological Survey: U.S. Geological Survey Water-Supply Paper 1839-D, $65 \mathrm{p}$.

Ramos-Ginés, Orlando, 1991, Elevation of the water table and reconnaissance of the hydrologic conditions in the Río Lapa to Río Majada area, Puerto Rico, for December 1988 and April, July, and October 1989: U.S. Geological Survey Water-Resources Investigation Report 90-4125, 1 pl.

Riggs, H.C., 1972, Low-flow investigations: U.S. Geological Survey Techniques of Water-Resources Investigations, Book C, Chapter B1, 18 p.

Searcy, J.K., 1959, Flow duration curves: U.S. Geological Survey Water-Supply Paper 1542-A, 33 p.

Shearman, J.D., Kirby, W.H., Schneider, V.R., and Flippo, H.N., 1986, Bridge waterways analysis model/research report: U.S. Federal Highway Administration Report FHWA/RD-86-108, $112 \mathrm{p}$.

Skougstad, M.W., Fishman, M.J., Friedman, L.C., Ardmann, D.E., and Duncan, S.S., 1979, Methods for determination of inorganic substances in water and fluvial sediments: U.S. Geological Survey, Investigation of the Techniques of Water-Resources , Book 5, Chapter A1, 626 p.

Theis, C.V., 1963, Estimating the transmissibility of a watertable aquifer from the specific capacity of a well: methods for determining permeability, transmissibility, and drawdown: U.S. Geological Survey Water-Supply Paper 1536-I, p. 332-336.

U.S. Environmental Protection Agency, 1986, Quality criteria for water: Office of Water Regulations and Standards, EPA440/5-86-001, $400 \mathrm{p}$.

U.S. National Oceanic and Atmospheric Administration, 1982, Monthly normals of temperature, precipitation, and heating and cooling degree days 1951-80, Puerto Rico, 12 p.

U.S. Weather Bureau, 1970, Substation Observations: Observing Handbook No. 2, 26 p.

Wood, P.R., Lang, R.F., and Payan, I.L., 1981, Anaerobic transformation, transport, and removal of volatile chlorinated organics in ground-water: Drinking Water Research Center, School of Technology, Florida International University, $20 \mathrm{p}$. 
APPENDIX 


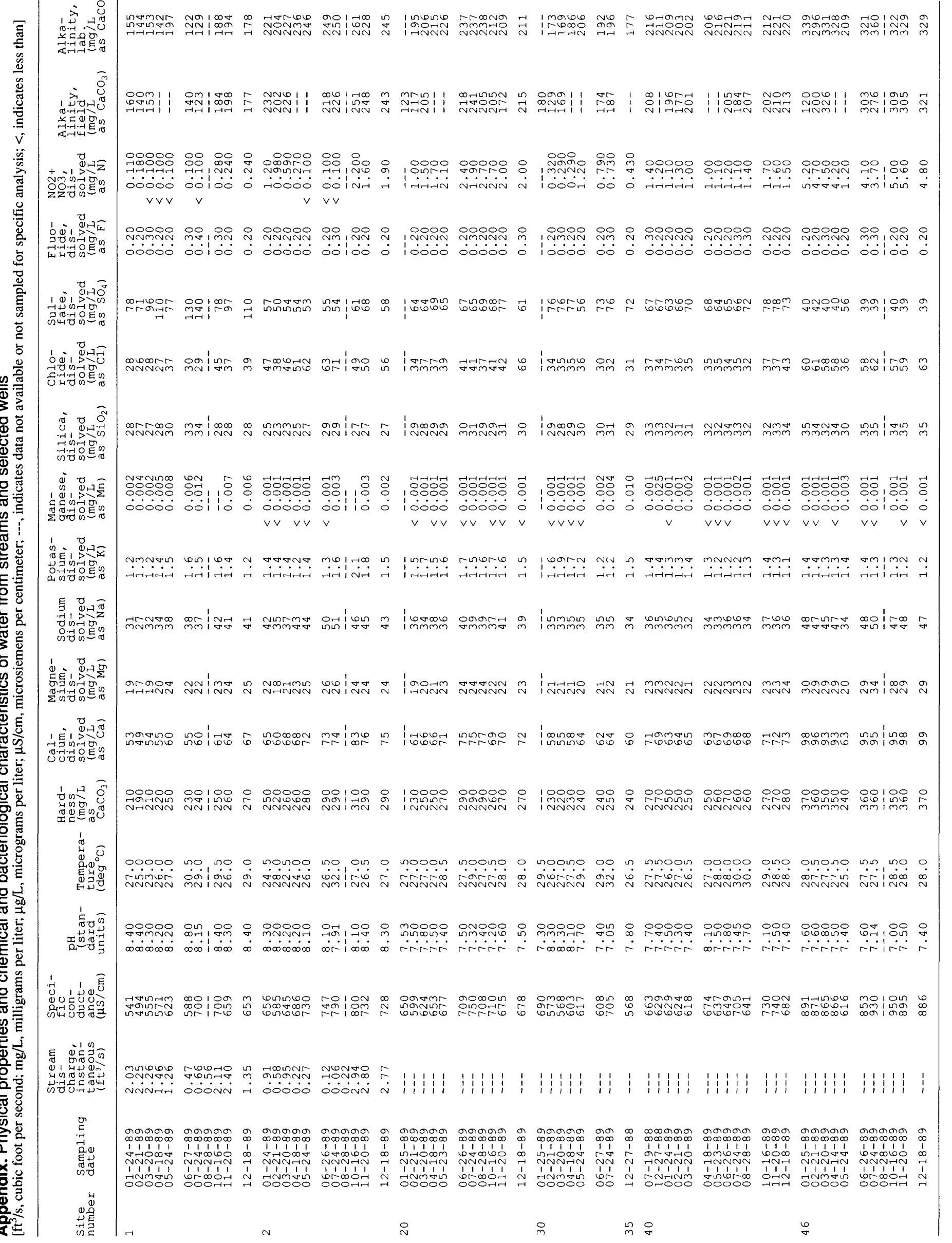




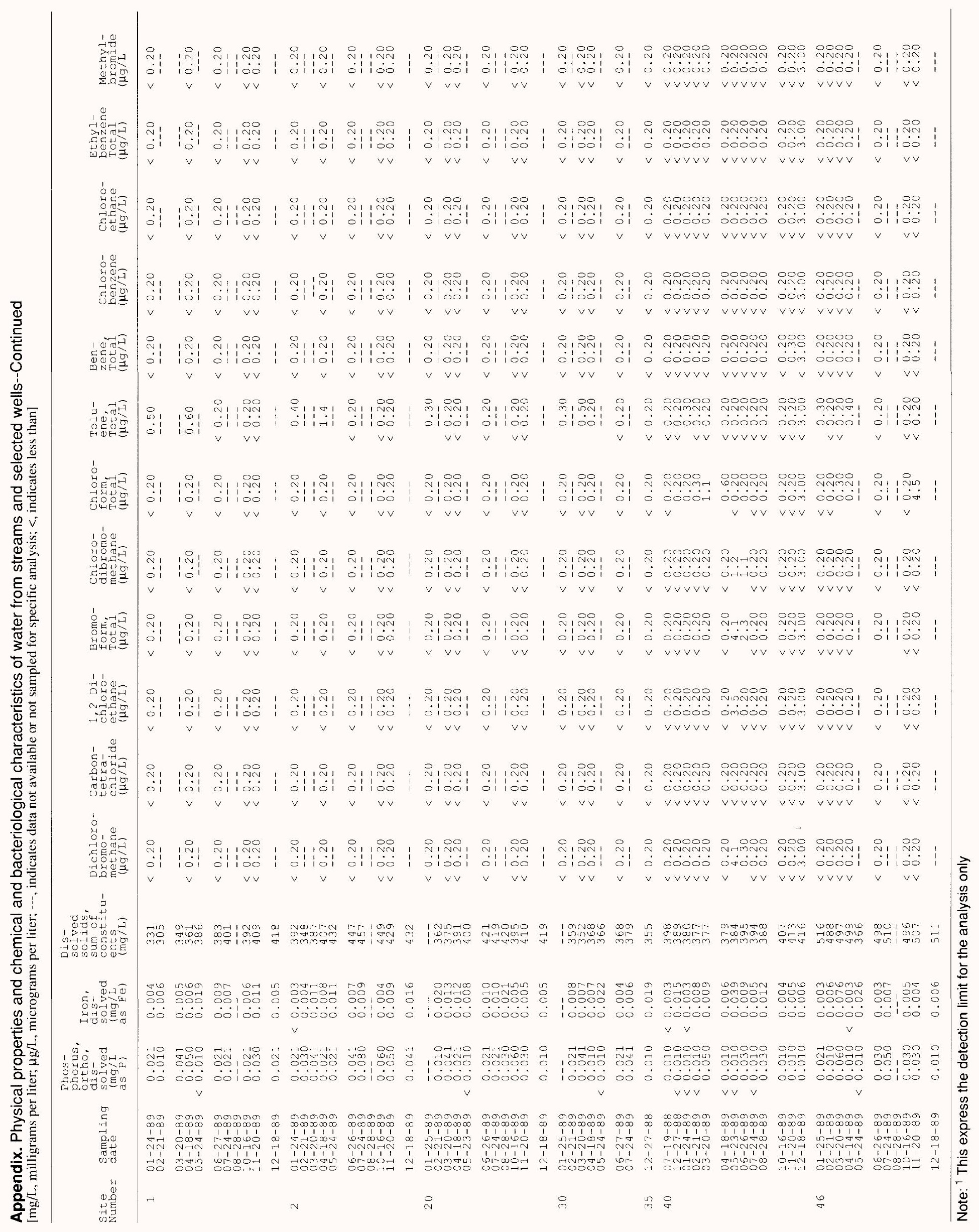




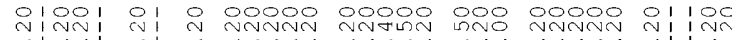

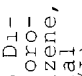

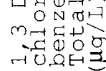

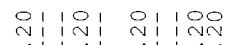

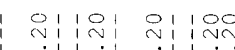

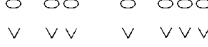

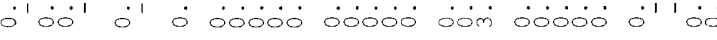

10

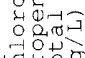

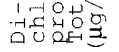

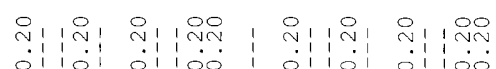

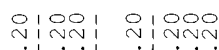

$\checkmark \vee v$

$\vee \vee \vee \vee \vee \vee \vee v$

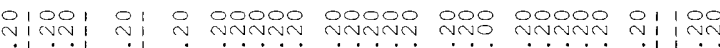

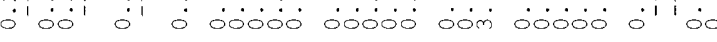
00,000

$\checkmark \vee v \vee v \vee v \vee v v v \vee v \vee v v \vee v v \vee v \vee v v \vee v \vee$

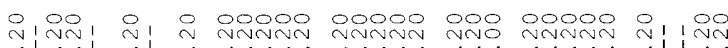

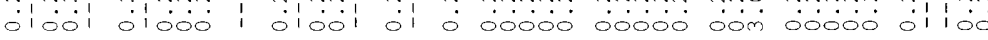
i

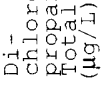

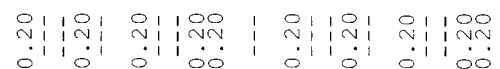

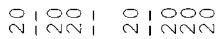

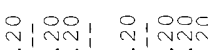
$\checkmark \vee v \vee v \vee v \vee v v \quad v \vee v \vee v \vee v v \vee v \vee v v \vee v \vee$

10

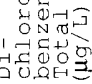

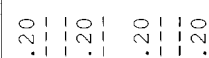

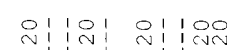

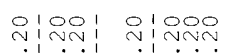

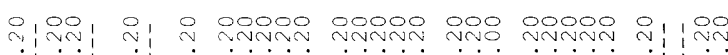

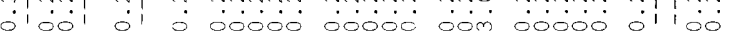

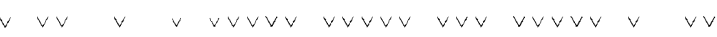

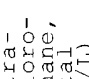
Aut

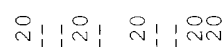

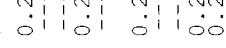

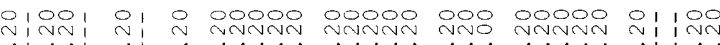

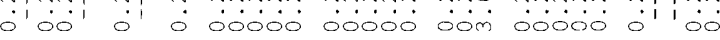
,

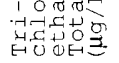

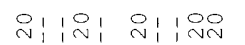
ㄴ: 1 Iㄴ:

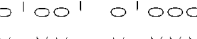

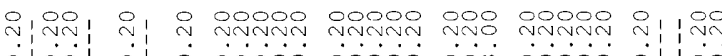

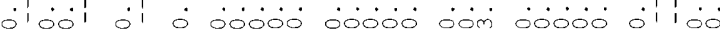
(1)

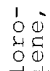

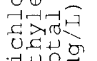

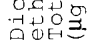

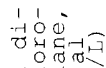

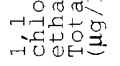

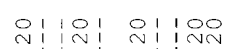

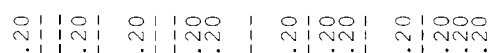

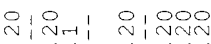
$\checkmark v v$

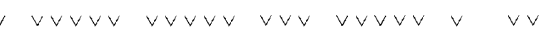

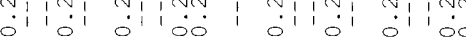

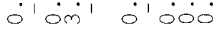

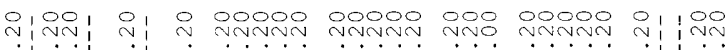

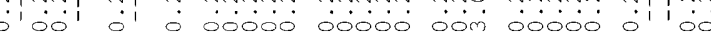

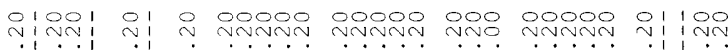

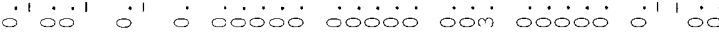

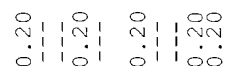

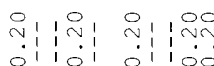

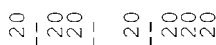

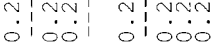

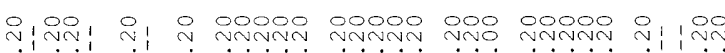

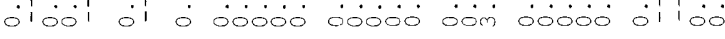

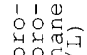

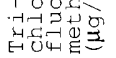

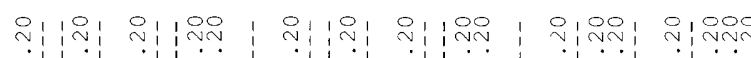
$\checkmark v \vee$

$\checkmark \vee v \vee v \vee v \vee v \vee v \vee v \vee v \vee v \vee v \vee v \vee$

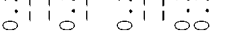
$0_{1}^{\prime 00^{\prime}} \cdot 1000$

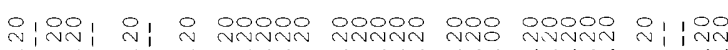

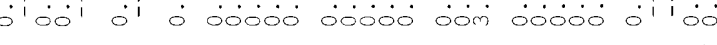

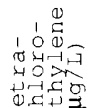

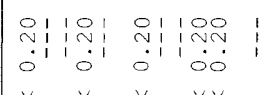

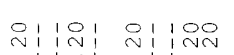

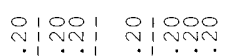

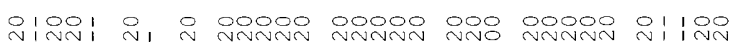
.10010 .1000 .10.

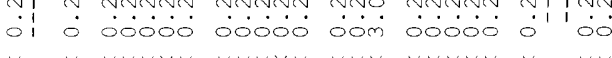

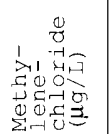

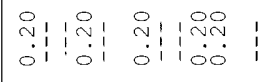

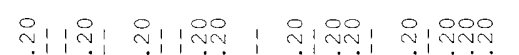

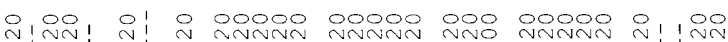

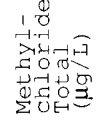

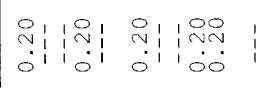

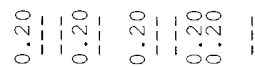

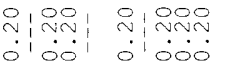

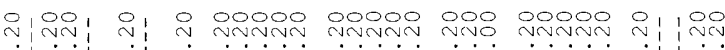

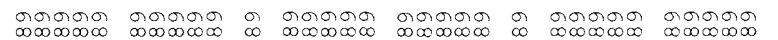

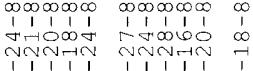

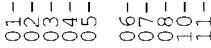
$\begin{array}{ll} & \\ 0 & \end{array}$

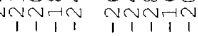

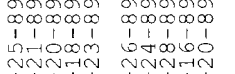

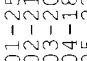

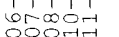

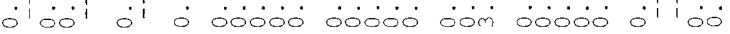
$\checkmark \vee v \vee v \vee v \vee v \vee v \vee v \vee v \vee v \vee v \vee v \vee v \vee v \vee v$

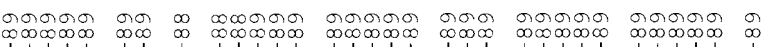

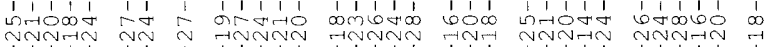

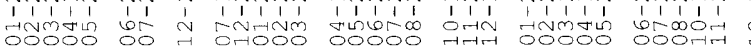




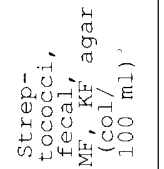

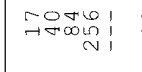
$\rightarrow+$

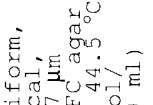
नᄀष्य

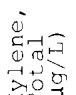

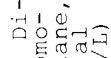

구ㅇㅝㅔ

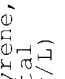

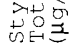

势

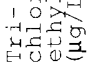

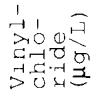

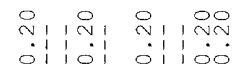

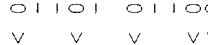

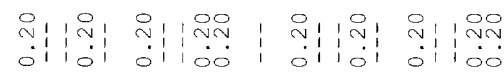

$v \vee v \quad v v$

ขึ)

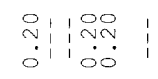

$\checkmark v$

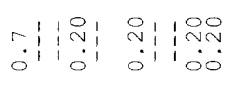

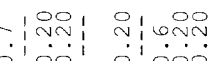

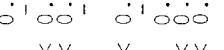

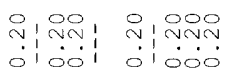

$\checkmark v \vee \quad v \vee v v$

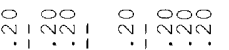

0.001000

$v \vee v \vee v \vee v v$

$\stackrel{0}{\mathrm{i}}$ ำ

$\begin{array}{lll}0 & 100 \\ V & \end{array}$

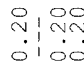

îj

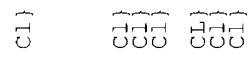

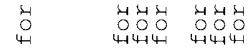

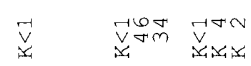

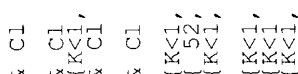

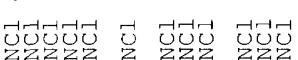

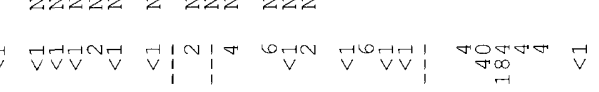

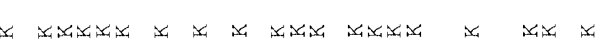

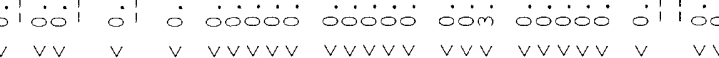

-

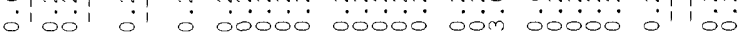
$\checkmark v \vee v \vee v \vee v v \vee v \vee v v \vee v v \quad v \vee v v \vee v \vee$

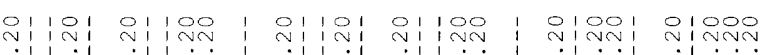

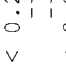

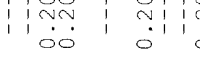

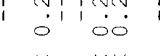

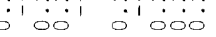

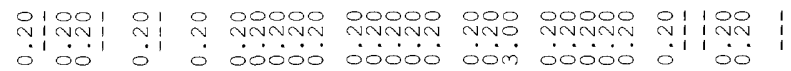
$\checkmark \vee v \vee v \vee v \vee v \vee v \vee v \vee v \vee v \vee v \vee v \vee v \vee v \vee v$

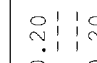

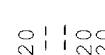

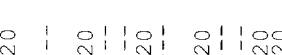

$\vee \vee v \quad v \vee v v$

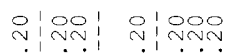

-

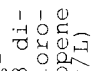

कितन

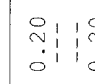

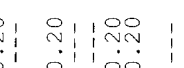

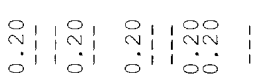

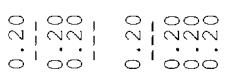

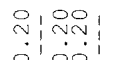

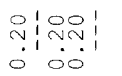

:

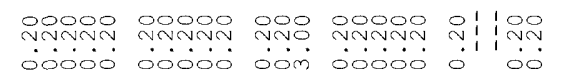

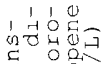

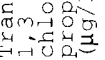

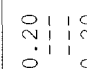

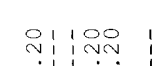

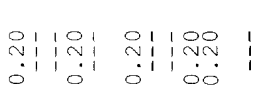

$v \vee v \vee v \vee v v$

$\vee \vee v$

$1:$

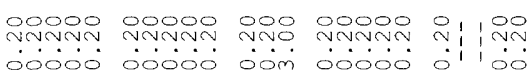

isini ininoo

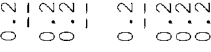

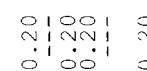

$\vee \vee v \vee v \vee v \vee v \vee v \vee v \vee v \vee v \vee v \vee v \vee$

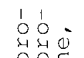

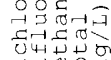

वैช

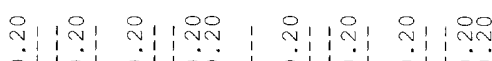

$\vee \vee \vee \quad \vee \vee \vee \vee$

$\checkmark \vee v$

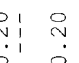

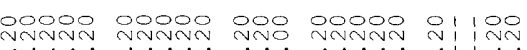
$\vee v \vee v$

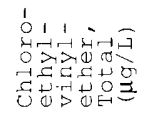

$\checkmark v v$ v

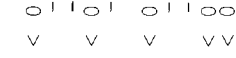

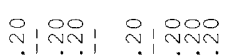

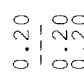

0
$v \vee v \vee v \vee v$

$\vee \vee v$

î!

ำ

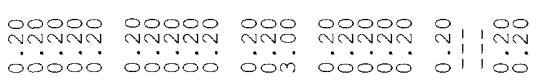

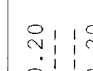

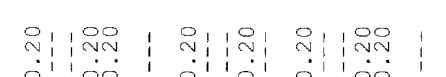

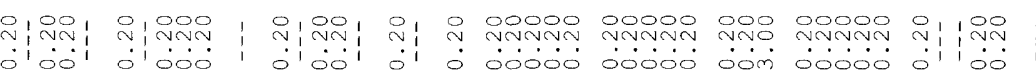

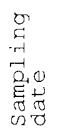

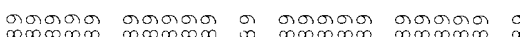

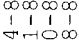

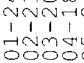

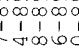

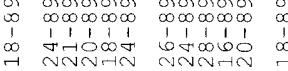

$v \vee v v v v v$

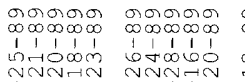

$v \vee v$

$1010 \% \pi$
$\infty 000000$
$\infty$

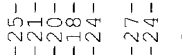

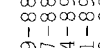

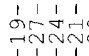

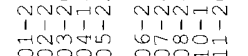

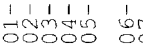

$\stackrel{\circ}{\vee}$

iे

$\stackrel{m}{m}$ \%

- U.S. GOVERMMENT PRINTING OFFICE: 1994-533-168/80012

Appendix 